\title{
10 Viren
}

Susanne Modrow

10.1 Aufbau und Einteilung der Viren - 326

10.2 Virusvermehrung und Replikation -330

10.2.1 Adsorption - 330

10.2.2 Aufnahme der Viruspartikel - 333

10.2.3 Freisetzung der Nucleinsäuren - 334

10.2.4 Genexpression und Replikation - 335

10.2.5 Regulation der viralen Genexpression und Replikation - 338

10.2.6 Morphogenese - 339

10.2.7 Freisetzung der Nachkommenviren - 340

10.3 Folgen der Virusinfektion für Wirtszelle und Wirtsorganismus -342

10.3.1 Zellschädigung und Viruspersistenz -342

10.3.2 Tumorbildung durch Viren -343

10.4 Diagnostik von Virusinfektionen - 346

10.4.1 Direkter Virusnachweis - 346

10.4.2 Bestimmung der Immunantwort gegen Virusproteine - 346

10.5 Prophylaxe und Therapie von Virusinfektionen - 348

10.5.1 Impfung -348

10.5.2 Chemotherapie -350

Literatur -353 
Viren sind kleine, aus Nucleinsäuren und Proteinen bestehende Infektionserreger, die gelegentlich von einer Membran umhüllt sind. Sie verhalten sich parasitär, da sie in die Zellen eines Organismus eindringen und sich dort vermehren. Hierbei müssen sie die Bestandteile der infizierten Wirtszellen für die Bildung von Nachkommenviren verwenden, da sie im Gegensatz zu Bakterien und Eukaryoten keinen eigenen Stoffwechsel besitzen. Für ihre Vermehrung stellen sie selbst lediglich die in ihren Genomen verankerten Informationen bereit. Virusinfektionen sind beim Menschen mit verschiedenen Erkrankungen wie Grippe, Masern, Windpocken, Kinderlähmung, Leberentzündung oder der Immunschwäche AIDS verbunden. Auch sind Viren kausal an der Entstehung von 15 bis 20 Prozent aller menschlicher Tumorerkrankungen beteiligt. Die moderne Molekularbiologie und Genetik hat in den letzten Jahrzehnten zu einer Explosion des Wissens über die Details des Virusaufbaus, die Art und Weise ihrer Vermehrung und ihrer Verbreitung geführt. Es floss in die Entwicklung von Impfstoffen zum Schutz vor Infektionen und von antiviralen Medikamenten zur Therapie der mit den Infektionen verbundenen Erkrankungen ein

\subsection{Aufbau und Einteilung der Viren}

(D Viren sind kleine Partikel aus Nucleinsäuren, Proteinen und Lipiden.

Aufbau von Viren. Infektiöse Viren, die auch als Virionen bezeichnet werden, sind kleine Partikel mit Durchmessern von $20 \mathrm{~nm}$ (Parvoviren) bis $300 \mathrm{~nm}$ (Pockenviren). Ihre geringe Größe macht sie ultrafiltrierbar, das heißt, sie werden von bakteriendichten Filtern nicht zurückgehalten. Sie bestehen aus folgenden Bestandteilen (- Abb. 10.1):

- Nucleinsäuren (DNA oder RNA), welche die Erbinformation des Virus darstellten

- Proteinen, die sich zu Hohlkörpern, den Capsiden, zusammenlagern und die Erbinformation des Virus einschließen

- Lipiden, welche als Membran (engl. envelope) die Capside umhüllen. In diese Membranhülle, die man nicht bei allen Virusarten findet, sind virale Membran- und Glycoproteine eingelagert. Die Viren können die Lipidbestandteile ihrer Membranen nicht selbst synthetisieren. Abhängig vom Virustyp verwenden die Infektionserreger hierfür Teile von zellulären Membranen wie der Plasmamembran, der Membranen des endoplasmatischen Retikulums oder der Golgi-Vesikel beziehungsweise der Kernmembran

Ein wichtiges Merkmal, in dem sich die Viren von Bakterien und eukaryoten Zellen unterscheiden ist, dass sie nur eine Art von Nucleinsäure - nämlich DNA oder RNA - enthalten. Diese stellt die Erbinformation der Erreger und kann abhängig vom Virustyp einzel- oder doppelsträngig vorliegen, linear, ringförmig oder segmentiert sein. Einzelsträngige RNA- und DNA-Genome können unterschiedliche Polarität aufweisen.

Die jeweiligen Genome

- sind in multimeren Proteinhohlkörpern, den Capsiden, eingeschlossen (z.B. Polio-, Gelbfieber oder Parvoviren), oder

- sind mit viralen Nucleoproteinen (z.B. Rhabdo-, Paraund Orthomyxoviren, Adeno- und Herpesviren) oder zellulären Histonen (Papillomviren) komplexiert und werden dann als Nucleocapside bezeichnet Nucleocapside können

- in Capside, eingeschlossen sein (z.B. Papillom-, Herpesoder Adenoviren (• Abb. 10.2a,b,c) oder

- ohne Capsidschicht nur von der Virusmembran umhüllt werden (z.B. Rhabdo, Para- oder den Orthomyxoviren)

Die Capside und auch die Nucleocapside sind helikale oder sphärische Gebilde aus einer variablen Zahl von identischen oder verschiedenen Proteinuntereinheiten, den Capsomeren. - Helikale Capside bilden eine röhrenförmige Struktur, welche die Nucleinsäure einschließt

- sphärische Capside haben einen ikosaedrischen Aufbau (- Abb. 10.2)

Wechselwirkung mit der Wirtszelle. Bei den Viren ohne Membran erfolgt die Wechselwirkung mit den Wirtszellen über Kontakte der Capsidoberflächen. Auch virusspezifische, neutralisierende Antikörper, die der Organismus wäh-

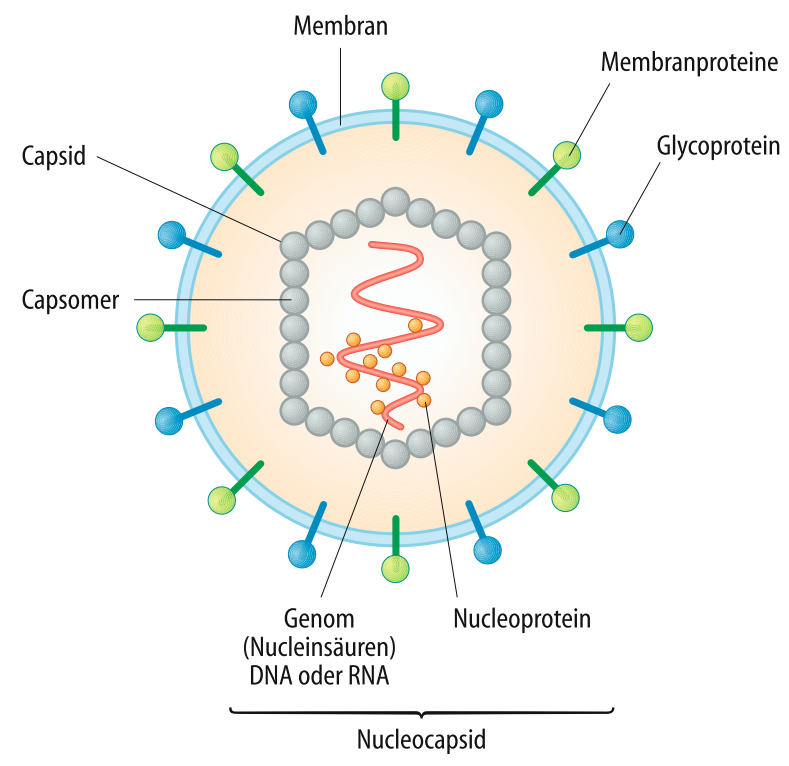

- Abb. 10.1. Aufbau eines Viruspartikels mit Membranhülle 

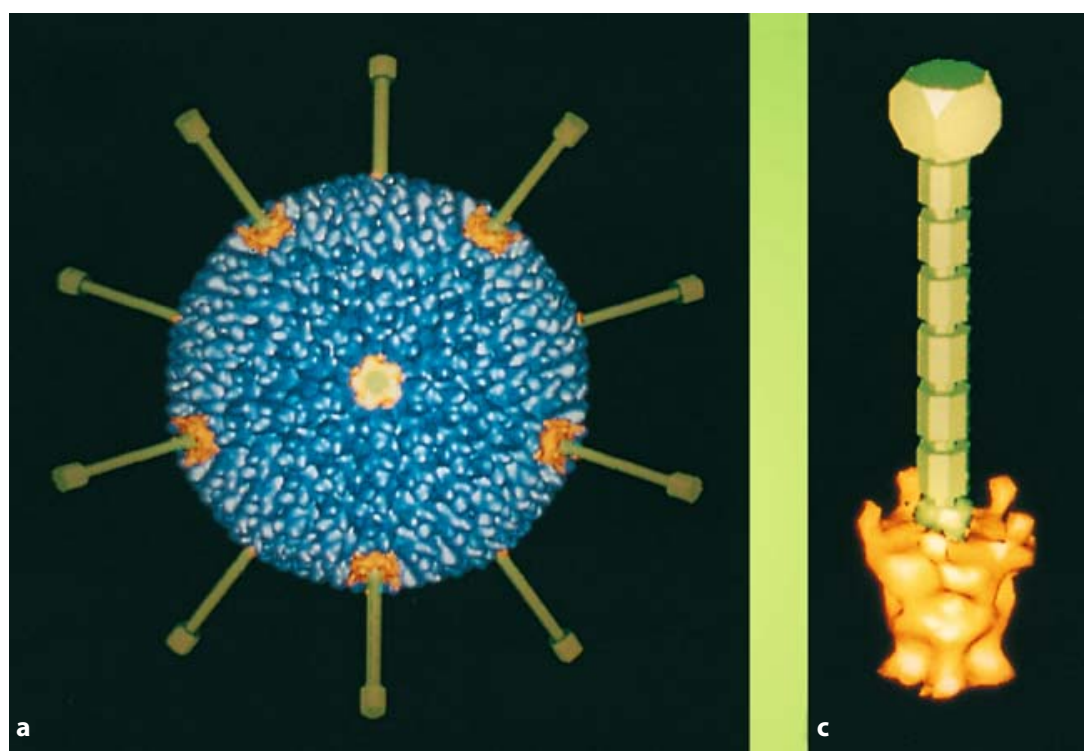

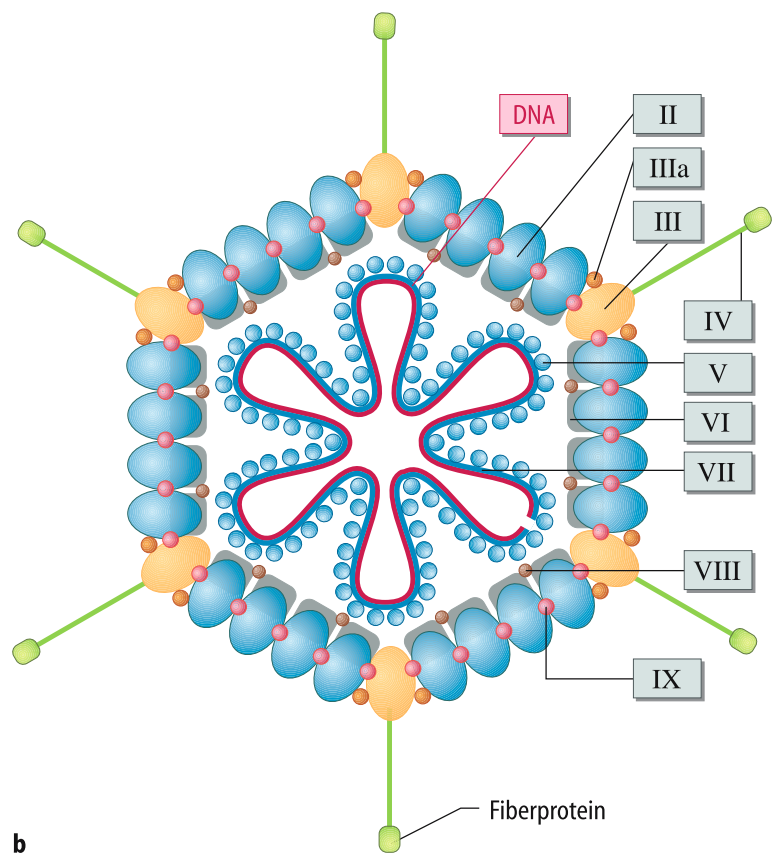

rend der Infektion als Teil der spezifischen Immunantwort ( $\vee$ Kap. 34.3) bildet, sind gegen Strukturen auf der Capsidoberfläche gerichtet. Im Unterschied hierzu besteht bei den membranumhüllten Viren die Partikeloberfläche aus den Komponenten der Lipidschicht und den in ihr verankerten Virusproteinen. Gegen diese richten sich in diesem Fall die vom Organismus produzierten Immunglobuline.

D Die Einteilung der Viren in Familien und Gattungen erfolgt nach ihren molekularen Eigenschaften.

Virusfamilien. In - Tabelle 10.1 sind die verschiedenen Virusfamilien mit wichtigen human- und auch tierpathogenen Vertretern zusammengefasst. Bei der Einteilung der
- Abb. 10.2a-c. Aufbau eines Adenovirus. a Modell des Capsids der Adenoviren. Das ikosaedrische Capsid besteht aus 52 Caspomeren. 240 von diesen haben jeweils sechs Nachbarproteine und bilden die Ikosaederecken (Hexone, blau). 12 Capsomeren sind an den Ecken lokalisiert (orange). Sie grenzen an jeweils fünf Nachbarproteine, weswegen man sie Pentone nennt. An ihnen entspringen die Fiberproteine (grün). (Aufnahme von P. Stewart und R. Burnett, Wistar Institut, Philadelphia) b Querschnitt durch ein Adenovirus. II bis IX sind verschiedene virale Strukturproteine, die das Partikel bilden (Protein I fehlt; es stellt sich bei genauen Untersuchungen als Komplex von zwei Proteinen heraus). Orange dargestellt sind die Pentone, (blau) die Hexone, (grün) die Fiberproteine. Im Inneren befindet sich das lineare, doppelsträngige DNA-Genom. (Verändert nach Brown DT et al. 1975) c Fiberproteine. Die Fiberproteine sind spikeartige Proteinvorsprünge, die mit den Pentonproteinen an den Ikosaederecken verknüpft sind und bis zu $30 \mathrm{~nm}$ aus der Partikeloberfläche hervorragen. Über die Knöpfchen an den Enden binden sich die Viren an die Rezeptoren auf der Oberfläche ihrer Zielzellen. (Aufnahme von P. Stewart und R. Burnett, Wistar Institut, Philadelphia)

Viren in die unterschiedlichen Familien wird nach folgenden Kriterien vorgegangen:

- Der Art des Genoms (RNA oder DNA), seines Aufbaus (Einzel- oder Doppelstrang, Positiv- oder Negativstrangorientierung, linear oder zirkulär geschlossen, segmentiert oder kontinuierlich). Auch die Anordnung und Abfolge der Gene auf der Nucleinsäure ist für die Zuordnung der Viren zu den einzelnen Familien wichtig

- Dem Vorhandensein einer Membranhülle

- Der Symmetrieform der Capside

Für die Unterteilung der Virusfamilien in verschiedene Gattungen (Genera) können dann unterschiedliche Para- 
- Tabelle 10.1. Molekularbiologische Charakteristika der verschiedenen Virusfamilien mit Angabe einiger typischer Vertreter

\begin{tabular}{|c|c|c|c|c|c|}
\hline Virusfamilie & $\begin{array}{l}\text { Genus/ } \\
\text { Unterfamilie }\end{array}$ & Beispiel & $\begin{array}{l}\text { Membran- } \\
\text { hülle }\end{array}$ & $\begin{array}{l}\text { Charakteristika } \\
\text { Partikelgröße/ } \\
\text { Form des Capsids } \\
\text { oder Nucleocapsids }\end{array}$ & $\begin{array}{l}\text { Genom } \\
\text { Art/Größe }\end{array}$ \\
\hline Picornaviridae & $\begin{array}{l}\text { Enterovirus } \\
\text { Rhinovirus } \\
\text { Cardiovirus } \\
\text { Aphthovirus }\end{array}$ & $\begin{array}{l}\text { Poliovirus } \\
\text { Coxsackievirus } \\
\text { Schnupfenvirus } \\
\text { Mengovirus } \\
\text { Maul- und Klauen- } \\
\text { seuche-Virus }\end{array}$ & nein & 28-30 nm/lkosaeder & $\begin{array}{l}\text { ssRNA, linear, } \\
\text { Positivstrang } \\
7 \text { 200-8 } 400 \text { Basen }\end{array}$ \\
\hline Caliciviridae & $\begin{array}{l}\text { Norovirus } \\
\text { Sapovirus }\end{array}$ & $\begin{array}{l}\text { Norwalk-Virus } \\
\text { Sapporovirus }\end{array}$ & nein & $27-34 \mathrm{~nm} / \mathrm{lkosaeder}$ & $\begin{array}{l}\text { ssRNA, linear, } \\
\text { Positivstrang, } \\
7500-8000 \text { Basen }\end{array}$ \\
\hline $\begin{array}{l}\text { Hepatitis-E- } \\
\text { Virus ähnliche }\end{array}$ & $\begin{array}{l}\text { Hepatitis-E-Virus } \\
\text { Hepatovirus }\end{array}$ & $\begin{array}{l}\text { Hepatitis-E-Virus } \\
\text { Hepatitis-A-Virus }\end{array}$ & nein & $25 \mathrm{~nm} / \mathrm{lkosaeder}$ & $\begin{array}{l}\text { ssRNA, linear, } \\
\text { Positivstrang, } \\
8000 \text { Basen }\end{array}$ \\
\hline Flaviviridae & $\begin{array}{l}\text { Flavivirus } \\
\text { Pestvirus } \\
\text { Hepacivirus }\end{array}$ & $\begin{array}{l}\text { Gelbfiebervirus } \\
\text { FSME-Virus } \\
\text { Schweinepestvirus } \\
\text { Hepatitis-C-Virus }\end{array}$ & ja & 40-50 nm/lkosaeder & $\begin{array}{l}\text { ssRNA, linear, } \\
\text { Positivstrang, } \\
10000 \text { Basen }\end{array}$ \\
\hline Togaviridae & $\begin{array}{l}\text { Alphavirus } \\
\text { Rubivirus }\end{array}$ & $\begin{array}{l}\text { Sindbisvirus } \\
\text { Semliki-Forest-Virus } \\
\text { Rötelnvirus }\end{array}$ & ja & $60-70 \mathrm{~nm} / \mathrm{lkosaeder}$ & $\begin{array}{l}\text { ssRNA, linear, } \\
\text { Positivstrang, } \\
10000-12000 \text { Basen }\end{array}$ \\
\hline Arteriviridae & Arterivirus & Equine-Arteritis-Virus & ja & 40-60 nm/lkosaeder & $\begin{array}{l}\text { ssRNA, linear, } \\
\text { Positivstrang, } \\
12000-16000 \text { Basen }\end{array}$ \\
\hline Coronaviridae & Coronavirus & $\begin{array}{l}\text { Humane Coronaviren } \\
\text { SARS-Virus } \\
\text { Virus der infektiösen Peri- } \\
\text { tonitis der Katze }\end{array}$ & ja & 80-160 nm/Helix & $\begin{array}{l}\text { ssRNA, linear, } \\
\text { Positivstrang, } \\
16000-21000 \text { Basen }\end{array}$ \\
\hline Rhabdoviridae & $\begin{array}{l}\text { Vesiculovirus } \\
\text { Lyssavirus }\end{array}$ & $\begin{array}{l}\text { Vesicular-Stomatitis-Virus } \\
\text { Tollwutvirus }\end{array}$ & ja & 65-180 nn/Helix & $\begin{array}{l}\text { ssRNA, linear, } \\
\text { Negativstrang, } \\
12000 \text { Basen }\end{array}$ \\
\hline Bornaviridae & Bornavirus & Bornavirus & ja & 90 nm/Helix? & $\begin{array}{l}\text { ssRNA, linear, } \\
\text { Negativstrang, } \\
9000 \text { Basen }\end{array}$ \\
\hline Paramyxoviridae & $\begin{array}{l}\text { Rubulavirus } \\
\text { Respirovirus } \\
\text { Morbillivirus } \\
\text { Pneumovirus } \\
\text { Metapneumovirus }\end{array}$ & $\begin{array}{l}\text { Mumpsvirus } \\
\text { Parainfluenzavirus } \\
\text { Masernvirus } \\
\text { Respiratorisches } \\
\text { Syncytialvirus } \\
\text { Humanes Metapneumo- } \\
\text { virus }\end{array}$ & ja & $150-250 \mathrm{~nm} /$ Helix & $\begin{array}{l}\text { ssRNA, linear, } \\
\text { Negativstrang, } \\
16000-20000 \text { Basen }\end{array}$ \\
\hline Filoviridae & Filovirus & $\begin{array}{l}\text { Marburg-Virus } \\
\text { Ebolavirus, } \\
\text { Restonvirus }\end{array}$ & ja & 80-700 nm/Helix & $\begin{array}{l}\text { ssRNA, linear, } \\
\text { Negativstrang, } \\
19000 \text { Basen }\end{array}$ \\
\hline Orthomyxoviridae & $\begin{array}{l}\text { Influenza-A-Virus } \\
\text { Influenza-B-Virus } \\
\text { Influenza-C-Virus }\end{array}$ & $\begin{array}{l}\text { Influenza-A-Viren } \\
\text { Influenza-B-Viren } \\
\text { Influenza-C-Viren }\end{array}$ & ja & $120 \mathrm{~nm} /$ Helix & $\begin{array}{l}\text { ssRNA, linear, } \\
\text { 7- bzw. } 8 \text { Segmente, } \\
\text { Negativstrang, } \\
13000-14600 \text { Basen }\end{array}$ \\
\hline Bunyaviridae & $\begin{array}{l}\text { Bunyavirus } \\
\text { Phlebovirus } \\
\text { Nairovirus } \\
\text { Hantavirus }\end{array}$ & $\begin{array}{l}\text { California-Enzephalitis- } \\
\text { Virus } \\
\text { Rift-Valley-Fieber Virus } \\
\text { Krim-Kongo-Fieber-Virus } \\
\text { Hantaanvirus } \\
\text { Puumalavirus }\end{array}$ & ja & $100-200 \mathrm{~nm} /$ Helix & $\begin{array}{l}\text { ssRNA, linear, } \\
3 \text { Segmente } \\
\text { Negativstrang } \\
12000 \text { Basen }\end{array}$ \\
\hline Arenaviridae & Arenavirus & $\begin{array}{l}\text { Lymphozytäres-Chorio- } \\
\text { meningitis Virus (LCMV) } \\
\text { Lassavirus } \\
\text { Juninfieber-Virus }\end{array}$ & ja & 50-300 nm/Helix & $\begin{array}{l}\text { ssRNA, linear, } \\
2 \text { Segmente, } \\
10000-12000 \text { Basen }\end{array}$ \\
\hline
\end{tabular}




\begin{tabular}{|c|c|c|c|c|c|}
\hline Virusfamilie & $\begin{array}{l}\text { Genus/ } \\
\text { Unterfamilie }\end{array}$ & Beispiel & $\begin{array}{l}\text { Membran- } \\
\text { hülle }\end{array}$ & $\begin{array}{l}\text { Charakteristika } \\
\text { Partikelgröße/ } \\
\text { Form des Capsids } \\
\text { oder Nucleocapsids }\end{array}$ & $\begin{array}{l}\text { Genom } \\
\text { Art/Größe }\end{array}$ \\
\hline Birnaviridae & Avibirnavirus & $\begin{array}{l}\text { Virus der infektiösen Bur- } \\
\text { sitis der Hühner }\end{array}$ & nein & $60 \mathrm{~nm} / \mathrm{lkosaeder}$ & $\begin{array}{l}\text { dsRNA, linear } \\
2 \text { Segmente }\end{array}$ \\
\hline Reoviridae & $\begin{array}{l}\text { Orthoreovirus } \\
\text { Orbivirus } \\
\text { Rotavirus }\end{array}$ & $\begin{array}{l}\text { Reoviren } \\
\text { Orungovirus } \\
\text { Rotaviren }\end{array}$ & nein & $70-80 \mathrm{~nm} / \mathrm{lkosaeder}$ & $\begin{array}{l}\text { dsRNA, linear, } \\
\text { 10/11/12 Segmente, } \\
\text { 18 000-19000 Basen }\end{array}$ \\
\hline Retroviridae & $\begin{array}{l}\alpha \text {-Retrovirus } \\
\beta \text {-Retrovirus } \\
\gamma \text {-Retrovirus } \\
\delta \text {-Retrovirus } \\
\text { Lentivirus } \\
\text { Spumavirus }\end{array}$ & $\begin{array}{l}\text { Rous-Sarcom-Virus } \\
\text { Maus-Mama-Tumor Virus } \\
\text { Felines Leukämievirus } \\
\text { Humane T-Zell- } \\
\text { Leukämie-Viren } \\
\text { Humane Immun- } \\
\text { defizienzviren } \\
\text { Humane Spumaviren }\end{array}$ & ja & $100 \mathrm{~nm} / \mathrm{lkosaeder}$ & $\begin{array}{l}\text { ssRNA, linear, } \\
\text { Positivstrang, } \\
\text { Umschreibung in } \\
\text { dsDNA, Integration } \\
7000-12000 \text { Basen }\end{array}$ \\
\hline Hepadnaviridae & $\begin{array}{l}\text { Orthohepadnavirus } \\
\text { Avihepadnavirus }\end{array}$ & $\begin{array}{l}\text { Hepatitis-B-Virus } \\
\text { Enten-Hepatitis-B-Virus }\end{array}$ & ja & $42 \mathrm{~nm}$ & $\begin{array}{l}\text { DNA, teilweise } \\
\text { doppelstängig; } \\
\text { zirkulär } \\
3000-3300 \text { Basen }\end{array}$ \\
\hline Polyomaviridae & SV40-ähnliche Viren & $\begin{array}{l}\text { BK, JC-Viren } \\
\text { SV40-Virus }\end{array}$ & nein & $45-50 \mathrm{~nm} / \mathrm{lkosaeder}$ & $\begin{array}{l}\text { dsDNA, zirkulär, } \\
5000-8000 \text { Basen }\end{array}$ \\
\hline Papillomaviridae & Papillomavirus & Humane Warzenviren & nein & $50-55 \mathrm{~nm} / \mathrm{lkosaeder}$ & $\begin{array}{l}\text { dsDNA, zirkulärer } \\
7000-8000 \text { Basen }\end{array}$ \\
\hline Adenoviridae & $\begin{array}{l}\text { Mastadenovirus } \\
\text { Aviadenovirus }\end{array}$ & $\begin{array}{l}\text { Humane Adenoviren } \\
\text { Geflügeladenvirus }\end{array}$ & nein & $60-80 \mathrm{~nm} / \mathrm{lkosaeder}$ & $\begin{array}{l}\text { dsDNA, linear, } \\
36000-38000 \text { Basen }\end{array}$ \\
\hline Herpesviridae & $\begin{array}{l}\alpha \text {-Herpesvirus } \\
\beta \text {-Perpesvirus } \\
\gamma \text {-Herpesviren }\end{array}$ & $\begin{array}{l}\text { Herpes-simplex } \\
\text { Varicella-Zoster } \\
\text { Cytomegalovirus } \\
\text { Humane Herpesviren 6/7 } \\
\text { Epstein-Barr-Virus } \\
\text { Humanes Herpesvirus } 8\end{array}$ & ja & $120-300 \mathrm{~nm} / \mathrm{lkosaeder}$ & $\begin{array}{l}\text { dsDNA, linear, } \\
15000-250000 \text { Basen }\end{array}$ \\
\hline Poxviridae & $\begin{array}{l}\text { Orthopoxviren } \\
\text { Avipoxviren } \\
\text { Molluscipoxvirus }\end{array}$ & $\begin{array}{l}\text { Variola-vera-Virus } \\
\text { Vacciniavirus } \\
\text { Kanarienpockenvirus } \\
\text { Molluscum contagiosum- } \\
\text { Virus }\end{array}$ & ja & $300-450 \mathrm{~nm} /$ komplex & $\begin{array}{l}\text { dsDNA, linear, } \\
130000-350000 \mathrm{Ba}- \\
\text { sen }\end{array}$ \\
\hline Parvoviridae & $\begin{array}{l}\text { Parvovirus } \\
\text { Erythrovirus } \\
\text { Dependovirus }\end{array}$ & $\begin{array}{l}\text { Feines Panleukopenie-Vi- } \\
\text { rus } \\
\text { Parvovirus B19 } \\
\text { Adeno-assoziierte Viren }\end{array}$ & nein & $20-25 \mathrm{~nm} / \mathrm{lkosaeder}$ & $\begin{array}{l}\text { ssDNA, linear, } \\
5000 \text { Basen }\end{array}$ \\
\hline Circoviridae & Circovirus & $\begin{array}{l}\text { Transfusion-transmitted } \\
\text { Virus } \\
\text { Chicken-Anämie-Virus }\end{array}$ & nein & $20 \mathrm{~nm} / \mathrm{lkosaeder}$ & $\begin{array}{l}\text { ssDNA, zirkulär } \\
3500 \text { Basen }\end{array}$ \\
\hline
\end{tabular}

meter herangezogen werden: Dazu zählen u.a. ob sie human-, tier- oder pflanzenpathogen sind, die Ähnlichkeit der Genomsequenzen, welche Zelltypen sie infizieren und auch welche Erkrankungen sie verursachen. Die weitere Einteilung in die verschiedenen Virustypen und -subtypen erfolgt dann meist nach serologischen Kriterien. Darunter versteht man das Ausmaß, in dem Antikörper, die der Organismus während der Infektion mit einem bestimmten Virustyp als Teil der spezifischen Immunantwort bildet und die sich spezifisch an dessen Oberflächenstrukturen binden, auch Komponenten eines mehr oder weniger verwandten Virus erkennen und sich daran binden.

Virusoide (Satellitenviren) sind kleine DNA- oder RNA-Moleküle, die für ein bis zwei Proteine codieren, mit welchen sie komplexiert sind. Ihre Replikation und Verbreitung ist von der Anwesenheit eines anderen Virus abhängig. Virusoide findet man meist zusammen mit Pflanzenviren, aber auch das humanpathogene Hepatitis-DVirus, das sich nur bei gleichzeitiger Infektion der Zelle mit Hepatits-B-Viren vermehren kann, gehört dazu. 


\section{In Kürze}

Viren

- sind kleine Partikel mit einer Größe von 20 bis 300 nm

- bestehen aus Proteinen und für die virale Erbinformation verantwortlichen Nucleinsäuren, außerdem bei einigen Viren einer Membranhülle aus Lipiden, die sich von zellulären Membranstrukturen ableitet

- verfügen im Unterschied zu Prokaryonten und Eukaryonten nur über eine Art von Nucleinsäure, nämlich DNA oder RNA
- haben keinen eigenen Stoffwechsel und verwenden für ihre Vermehrung und die Produktion ihrer Nachkommen die Energie- und Syntheseleistungen der Wirtszellen

- werden nach den molekularen Charakteristika ihrer Erbinformation und ihrer Viruspartikel in Familien und Gattungen eingeteilt

\subsection{Virusvermehrung und Replikation}

(8) Als Zellschmarotzer sind Viren auf die Infektion geeigneter Wirte und Wirtszellen angewiesen.

Viren sind intrazelluläre Parasiten, die mit einer sehr begrenzten Anzahl von Genen in ihrer Erbinformation auskommen. Sie verfügen nicht über eigene Stoffwechselsysteme oder die für eukaryote Organismen typischen Organellen. Bei allen Leistungen, die mit diesen Komponenten verbunden sind, müssen die Viren auf entsprechende Funktionen der Zellen zugreifen. Deswegen sind sie im Unterschied zu Bakterien und eukaryoten Zellen nicht in der Lage, sich durch Teilung zu vermehren. Stattdessen haben Viren Mechanismen entwickelt, in Zellen hineinzugelangen - sie zu infizieren - und die Wirtszellen zur Produktion einer Vielzahl neuer Viren zu veranlassen. Dabei bestimmen sowohl die molekularen Charakteristika der verschiedenen Viren, als auch der Typ der infizierten Zelle den Ablauf der Virusvermehrung. Er lässt sich trotz der Verschiedenheit der Details generell in relativ gut definierte, zeitlich aufeinander folgende Phasen einteilen.

- Adsorption. Die infektiösen Viruspartikel binden sich spezifisch an bestimmte Rezeptoren auf der Zelloberfläche

- Partikelaufnahme oder Penetration. Die Viren werden in das Cytoplasma der Zelle aufgenommen

- Freisetzung der Nucleinsäure (Uncoating). Das Virusgenom löst sich von den Strukturproteinen

- Virale Genexpression (Transkription, Translation). Die Gene im Virusgenom werden exprimiert und es erfolgt die Synthese verschiedener Nichtstruktur- und Strukturproteine

- Genomreplikation. Es erfolgt die Vervielfältigung der viralen Erbinformation

- Morphogenese (virus assembly). Die neu gebildeten viralen Strukturproteine und Genome lagern sich in einem geordneten Mechanismus zu Viruspartikeln zusammen
- Freisetzung. Die Nachkommenviren werden von den infizierten Zellen abgegeben und können sich weiter verbreiten

\subsubsection{Adsorption}

D Die Viren wählen durch spezifische Wechselwirkungen mit Oberflächenmolekülen die infizierbaren Wirtszellen aus.

Prinzip der Adsorption von Viren. Um eine Zelle zu infizieren, müssen Viren in der Lage sein, bestimmte Rezeptormoleküle auf der Oberfläche der Plasmamembran zu erkennen und sich an diese anzuheften. Diesen Prozess bezeichnet man als Adsorption. Bei membranumhüllten Viren wird diese Wechselwirkung durch Proteine in der Membranhülle vermittelt. Bei den membranlosen Viren erfolgt die Interaktion durch Proteinstrukturen auf der Capsidoberfläche.

Als zelluläre Rezeptoren können abhängig vom Virustyp unterschiedliche Oberflächenkomponenten benutzt werden (•Tabelle 10.2):

- Zelluläre Membranproteine beziehungsweise bestimmte Proteindomänen von diesen

- Kohlenhydrate (Oligosaccharide), die sich als Modifikation an zellulären Glycoproteinen befinden

- Glycolipide als Komponenten der Plasmamembran

Die Bindung der Viruspartikel an die zellulären Oberflächenstrukturen ist i.d.R. hoch spezifisch. Sie entscheidet, welchen Zelltyp die verschiedenen Viren infizieren können. Die Spezifität der Wechselwirkung ist aber auch dafür verantwortlich, dass selbst nah miteinander verwandte Viren die Speziesschranke nur selten überspringen können.

Spezifität der Virusadsorption. Bestimmte Viren, beispielsweise die humanen Immundefizienzviren (HIV, • Abb. $10.3 a, b)$, benötigen für eine erfolgreiche Infektion der Zellen die gleichzeitige Bindung an zwei Membranproteine. 


\begin{tabular}{|c|c|c|}
\hline Zelloberflächenmolekül & Virus & Virusfamilie \\
\hline \multicolumn{3}{|l|}{ Proteine } \\
\hline CD4-Rezeptor + Chemokinrezeptor & HIV & Retroviren \\
\hline CD55 (decay accelerating factor) & $\begin{array}{l}\text { Echovirus } 3,6,7,11-13,21,24 \\
\text { Coxsackievirus A2, B1, 3,5 }\end{array}$ & $\begin{array}{l}\text { Picornaviren } \\
\text { Picornaviren }\end{array}$ \\
\hline ICAM-1 (CD54) & $\begin{array}{l}\text { Rhinovirus, major group } \\
\text { Coxsackievirus } A 13,18,21\end{array}$ & $\begin{array}{l}\text { Picornaviren } \\
\text { Picornaviren }\end{array}$ \\
\hline LDL-Rezeptor & Rhinovirus minor group & Picornaviren \\
\hline CD155 & Poliovirus & Piconaviren \\
\hline Vitronectin-Rezeptor & $\begin{array}{l}\text { Coxsackievirus A9 } \\
\text { Maul- und Klauenseuche }\end{array}$ & $\begin{array}{l}\text { Picornaviren } \\
\text { Picornaviren }\end{array}$ \\
\hline SLAM-Protein (CD150) & Masernvirus & Paramyxoviren \\
\hline CD21 (Komplement-Rezeptro C3 d) & Epstein-Barr-Virus & Herpesviren \\
\hline Aminopeptidase $\mathrm{N}$ & Coronaviren, 229E-Gruppe & Coronaviren \\
\hline$\alpha$-Dystroglucan & Lassavirus & Arenaviren \\
\hline \multicolumn{3}{|l|}{ Kohlenhydrate und Glycolipide } \\
\hline Sialinsäure (N-Acetyl-Neuraminsäure) & $\begin{array}{l}\text { Influenzaviren } \\
\text { Parainfluenzaviren }\end{array}$ & $\begin{array}{l}\text { Orthomyxoviren } \\
\text { Paramyxoviren }\end{array}$ \\
\hline Heparansulfat & Herpes-simplex-Viren & Herpesviren \\
\hline Globosid (Blutgruppen-Antigen P) & Parvovirus B19 & Parvovirus \\
\hline
\end{tabular}

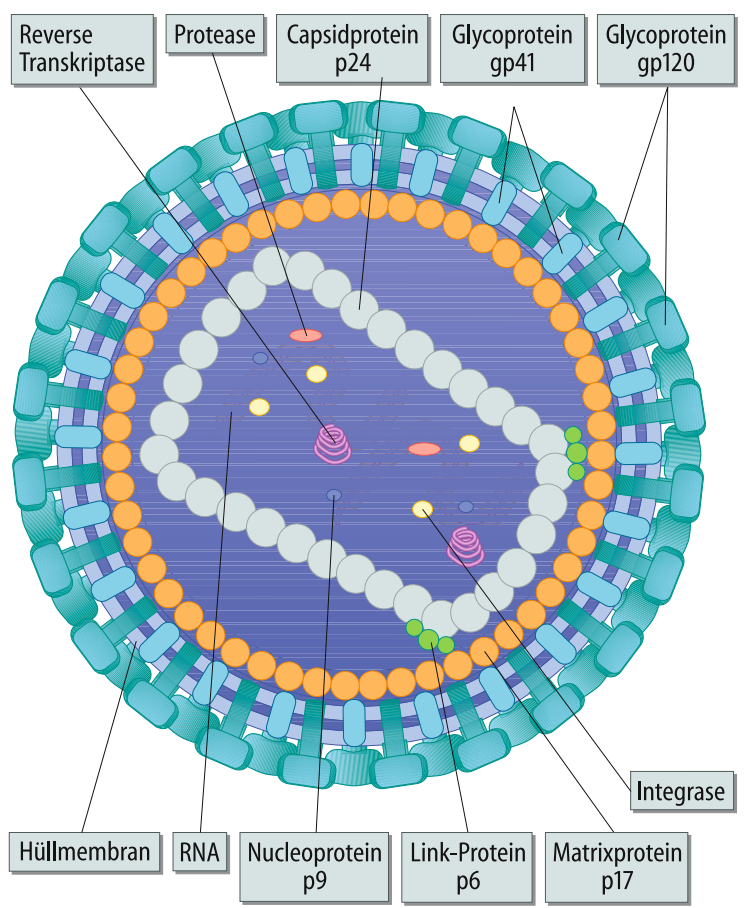

a

- Abb. 10.3a, b. Aufbau eines humanen Immundefizienzvirus. a Modell eines humanen Immundefizienzvirus (HIV) im Querschnitt. Das Virus ist von einer Membranhülle umgeben, in welche der Komplex der viralen Glycoproteine (gp120/gp41) eingelagert ist. Im Inneren findet man das virale Capsid (Core) mit dem Genom. Dieses be-

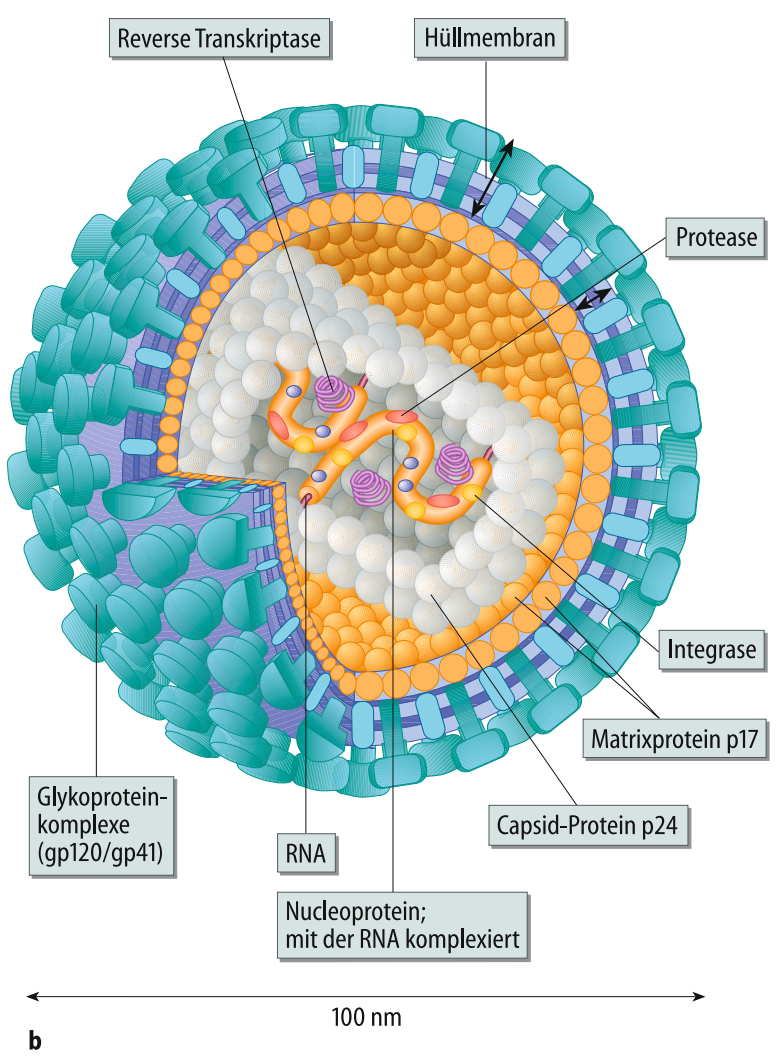

steht aus zwei Kopien einer einzelsträngigen RNA, die mit den viralen Nucleoproteinen zu Nucleocapsiden interagieren. b Räumliches Modell eines humanen Immundefizienzvirus (HIV). (Nach Gatermann und Gelderblom, Copyright Spiegel-Verlag, Hamburg, modifiziert nach Löffler u. Petrides 1998) 


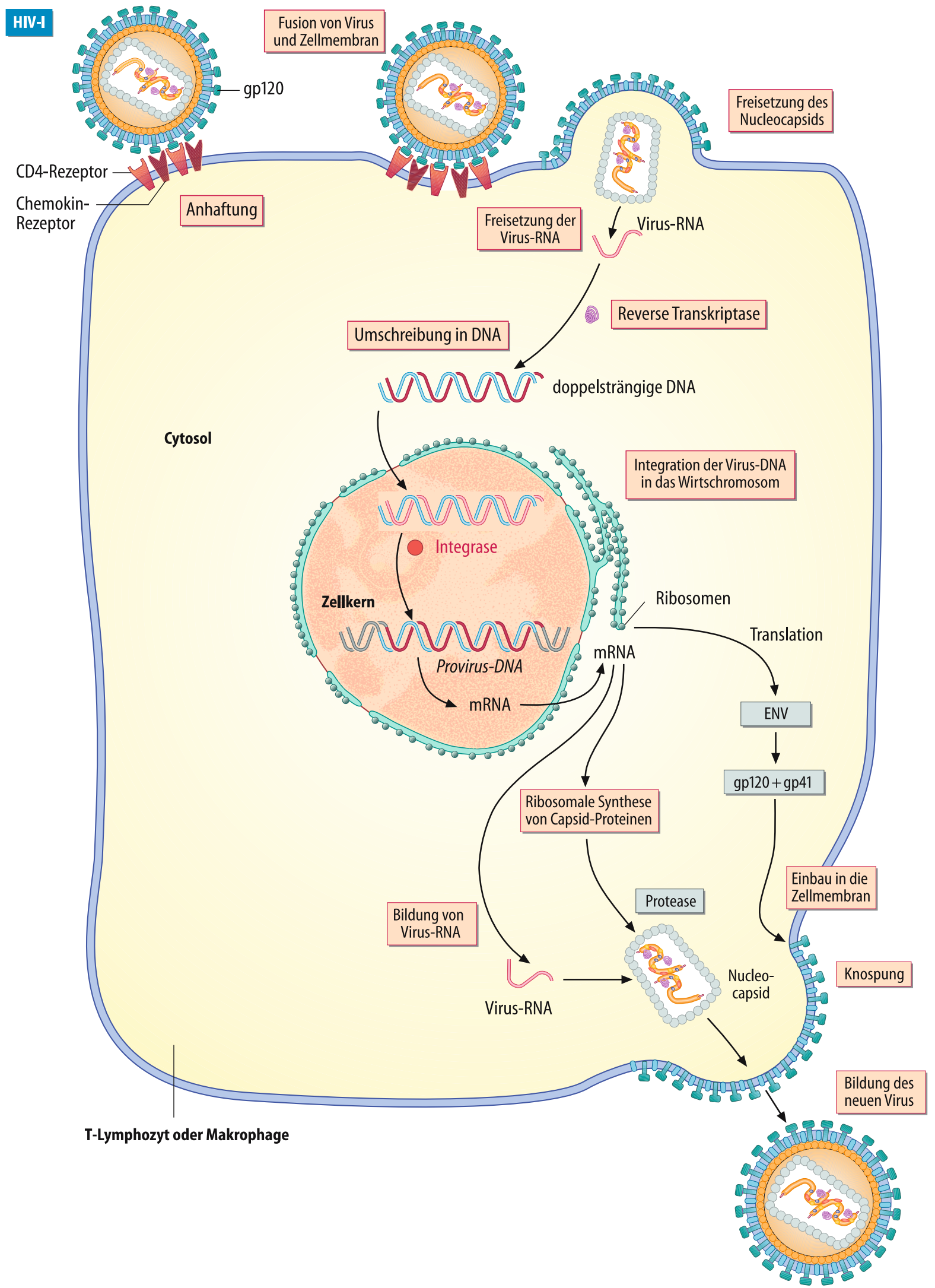


Abb. 10.4. Infektion einer Zelle mit dem humanen Immundefizienzvirus. Für die Bindung des Virus an die Zelloberfläche und seine nachfolgende Aufnahme ist zusätzlich zu dem CD4-Protein ein Chemokinrezeptor notwendig. Dabei kann es sich entweder um einen CC-Chemokinrezeptor oder einen CXC-Chemokinrezeptor handeln. Sie bestimmen den Zelltropismus des Virus und sind dafür verantwortlich, ob die Virusvarianten Makrophagen oder T-Lymphozyten infizieren. Nach der Aufnahme des Virus, der Freisetzung des Genoms und seine Umschreibung in doppelsträngige DNA wird die ProvirusDNA in das zelluläre Genom eingebaut. Von dort werden die einzelnen viralen Gene transkribiert und translatiert, sodass anschließend die Assemblierung neuer Viren und deren Freisetzung durch Knospung erfolgen kann. ENV = Translationsprodukt des ENV-Gens, aus dem die Transmembranproteine gp120 und gp41 geschnitten werden

Das Oberflächenprotein gp120 dieser Viren bindet an die aminoterminale Domäne des CD4-Proteins, eines Zelloberflächenmarkers der Plasmamembran von T-Helferzellen, Monozyten oder Makrophagen (• Abb. 10.4). Welche der beiden Zelltypen von den HI-Viren infiziert werden, wird durch die gleichzeitige Wechselwirkung des gp120 mit unterschiedlichen Chemokin-Rezeptoren bestimmt, die sich entweder in der Plasmamembran der Makrophagen (Rezeptor CCR5 für die CC-Chemokine Rantes, MIP-1 $\alpha$, MIP-1 $\beta$ ) oder derjenige der T-Lymphozyten (CXCR4Rezeptor für CXC-Chemokine, z.B. SDF-1) befinden. Geringfügige Unterschiede in der Aminosäuresequenz des viralen Oberflächenproteins gp120 entscheiden über seine Bindung an die jeweiligen Chemokin-Rezeptoren und bestimmen so die Zellspezifität der HIV-Subtypen.

Auch das nicht von einer Membran umhüllte Adenovirus (• Abb. 10.2a,b) benötigt zwei Rezeptoren, um mit ausreichender Affinität und Spezifität an seine Wirtszellen - meist Epithelzellen - zu binden (• Abb. 10.5a). Über knöpfchenartige Strukturen am Ende der Fiberproteine, die an den zwölf Ikosaederecken lokalisiert sind und aus der
Capsidoberfläche hervorragen, bindet es an den CARRezeptor (cocksackie- and adenovirus-receptor), ein Zelloberflächenprotein unbekannter Funktion. Zugleich findet eine Wechselwirkung der sog. Pentonbasisproteine - sie verbinden die Fiberproteine mit der Capsidoberfläche der Adenoviren - mit Integrin $\alpha_{\mathrm{v}} \beta_{3}$ oder $\alpha_{\mathrm{v}} \beta_{5}$ auf der Zelloberfläche statt.

\subsubsection{Aufnahme der Viruspartikel}

D Die Aufnahme der Viren in das Cytoplasma erfolgt durch Rezeptor-vermittelte Endozytose oder durch Fusion von Virus- und Zellmembran.

Nach der Adsorption wird das an die Zelloberfläche gebundene Virus in das Cytoplasma aufgenommen. Dies kann auf zweierlei Arten erfolgen:

- Rezeptor-vermittelte Endozytose der Viruspartikel oder

- Fusion der Virusmembran mit der Plasmamembran

Bei den meisten Viren erfolgt die Aufnahme der Viruspartikel durch Rezeptor-vermittelte Endozytose (• Abb. 10.5b-d). Insbesondere bei den Adenoviren und bei den Polioviren konnte man zeigen, dass die Vesikel hohe Konzentrationen des zellulären Proteins Clathrin besitzen und damit alle Eigenschaften von Clathrin-Vesikeln aufweisen $(\triangleright$ Kapitel 6, S.180). Nach der Endozytose befinden sich derartige Viren in intrazellulären Vesikeln, den Endosomen.

Die Herpesviren, die Paramyxoviren (Erreger von Masern und Mumps) sowie die humanen Immundefizienzviren (• Abb. 10.4) verwenden dagegen einen anderen Weg in das Zellinnere. Sie verfügen in der Virusmembran über Proteine, die nach Rezeptor-vermittlter Adsorption die

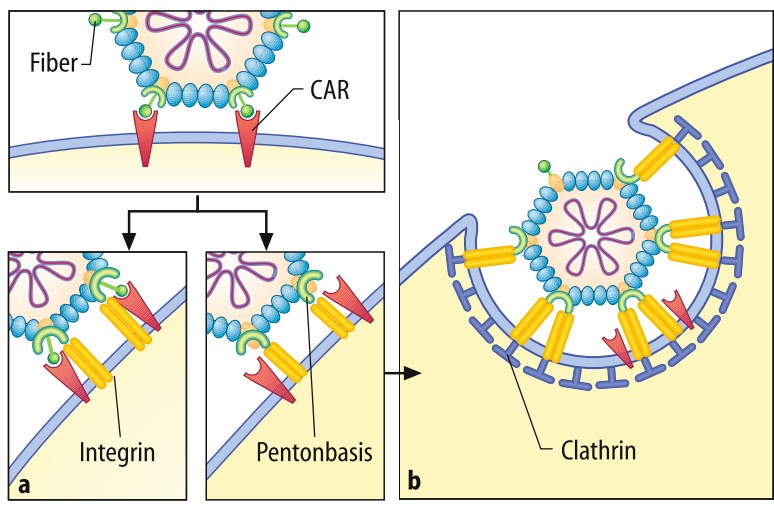

- Abb. 10.5a-d. Virusaufnahme durch rezeptorvermittelte Endozytose am Beispiel des Adenovirus. a Bindung an die Zelloberfläche. Die Fiberproteine binden an den CAR (Coxsackie- und Adenovirusrezeptor). Dadurch kommt es zu einer Konformationsänderung der Pentonbase. Diese interagiert jetzt mit den Integrinen $\alpha_{v} \beta_{3}$ oder $\alpha_{v} \beta_{5}$, außerdem werden die Fibern abgelöst. b Das Clustern der Integrine ermöglicht die Aufnahme der Viruspartikel in coated

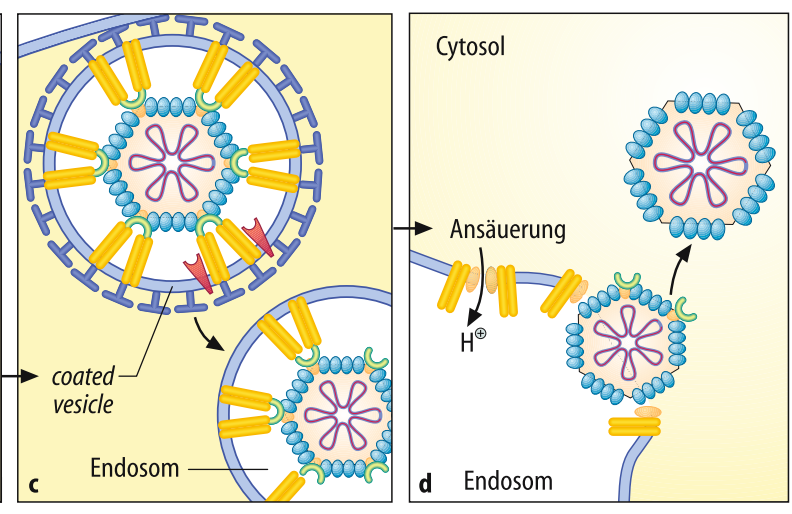

pits mit der anschließenden Bildung Clathrin-reicher Membranvesikel. c Die Clathrin-reichen Vesikel geben Clathrin ab und werden zu Endosomen. d Der Endosomeninhalt wird durch die Aktivität einer zellulären Protonenpumpe angesäuert. Dadurch kommt es an den Kontaktstellen zwischen der Virusoberfläche und der Endosomenmembran zu strukturellen Umlagerungen und das Virus gelangt in das Cytoplasma 

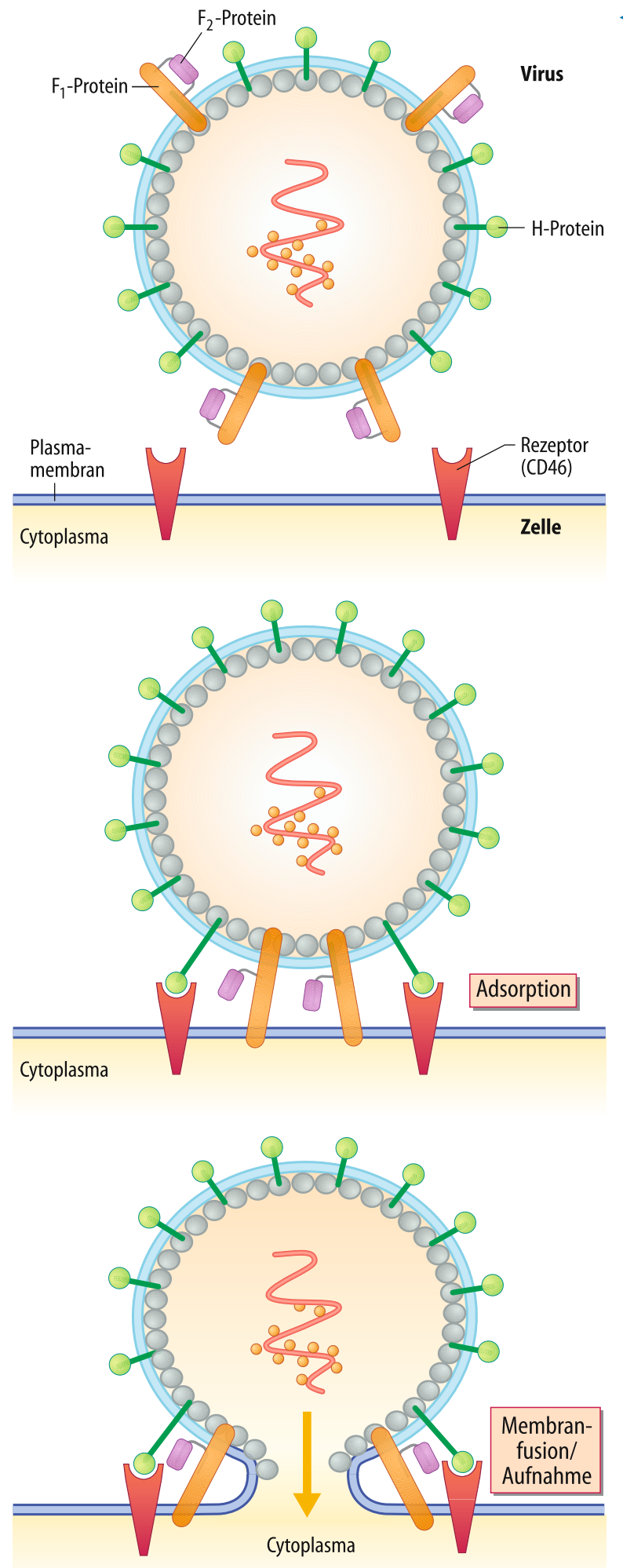

4 Abb. 10.6. Virusaufnahme durch Fusion der Virus- mit der Zellmembran am Beispiel eines Paramyxovirus (Masernvirus). Das Viruspartikel bindet sich über sein Oberflächenprotein $\mathrm{H}$ an das CD46-Protein in der Plasmamembran der Zielzelle. Das F1/F2-Protein lagert das aminoterminale Ende seiner F1-Untereinheit in die Membran der Zielzelle ein und vermittelt so einen engen Kontakt zwischen Virusmembran und Cytoplasmamembran. Beide verschmelzen miteinander. Das Nucleocapsid des Virus, das aus Proteinen und einer einzelsträngigen RNA (Genom) besteht, gelangt dadurch in das Cytoplasma der Zelle. Schematische Darstellung, die Einzelheiten des Vorgangs sind noch nicht geklärt

Fusionierung von Virusmembran mit der Plasmamembran der Wirtszelle ermöglichen. (• Abb. 10.6). Bei den Paramyxoviren ist für die Membranfusion die aminoterminale Domäne des viralen Transmembranproteins $\mathrm{F}_{1}$ verantwortlich, bei den humanen Immundefizienzviren der aminoterminale Teil des Transmembranproteins gp41. Die fusionsaktiven Domänen entstehen während des Virusassembly, wenn die Vorläuferproteine $\mathrm{F}_{0}$ (Paramyxoviren) oder gp160 (humane Immundefizienzviren) nach ihrer Synthese durch zelluläre Proteasen, beispielsweise Furin, in den Golgi-Vesikeln gespalten werden. Die an den Spaltprodukten neu entstandenen aminoterminalen Enden können dann die Fusion zwischen Virus und Plasmamembran einleiten. Dadurch gelangen die Capside in das Cytoplasma der Zelle.

\subsubsection{Freisetzung der Nucleinsäuren}

( Unter uncoating versteht man in der Virologie die intrazelluläre Freisetzung der viralen Nucleinsäuren.

Damit die Infektion sich in der Zelle etablieren kann, muss das Virusgenom von den Protein- und Lipidschichten, die es einschließen, befreit werden. Im Fall der Rezeptor-vermittelten Aufnahme liegen die Viren zunächst in Vesikeln, vor. Diese verschmelzen mit frühen Endosomen, in deren Membran Protonen-ATPasen eingelagert sind, die durch ATP-abhängigen Import von $\mathrm{H}^{+}$-Ionen die Ansäuerung des Endosomeninneren bewirken ( $\triangleright$ Kapitel 6.2.7). Dies hat strukturelle Umlagerungen bei den Virusoberflächenproteinen zur Folge: Bei den membranumhüllten Viren kommt es dadurch zur Aktivierung von fusionsaktiven Domänen, beispielsweise im $\mathrm{HA}_{2}$-Teil des HA-Proteins (Hämagglutinin) der Influenzaviren, die im nächsten Schritt die Verschmelzung von Virus- und Endosomenmembran einleiten. Die Nucleocapside und Capside können dadurch ins das Cytoplasma übertreten. Auch die mit den Genomen assoziierten Proteine verändern in dem sauren Milieu ihre Konformation sowie ihre feste Bindung an die Nucleinsäuren, bleiben jedoch in aller Regel mit ihnen assoziiert. Die Influenzaviren besitzen sogar eigene Protonentransportproteine (M2-Proteine), die diesen Ansäuerungsvorgang zusätzlich fördern. 
Auch bei den nicht von einer Membran umhüllten Viren (beispielsweise den Adeno- oder den Polioviren) bedingt die Ansäuerung des Endosomeninhalts Strukturveränderungen der Capsidproteine. An den Kontaktstellen zwischen der Capsidoberfläche und der Innenseite der Endosomenmembran verändert diese ihre Fluidität und wird porös, sodass auch hier ein direkter Kontakt zwischen den Nucleocapsiden und dem Cytoplasma hergestellt ist (• Abb. 10.5). Im Detail sind diese Vorgänge aber noch weitgehend unverstanden.

Bei Viren, die - wie die Paramyxoviren - bereits bei der Adsorption die Verschmelzung von Virus- und Zellmembran induzierten, liegen die Nucleocapside schon nach diesem Schritt im Cytoplasma vor.

Über die Abtrennung der Nucleinsäuren von den assoziierten Proteinen der Nucleocapside weiß man noch sehr wenig.

\subsubsection{Genexpression und Replikation}

Im nächsten Schritt des Infektionszyklus müssen die in den Genomen enthaltenen Erbinformationen in Proteine umgesetzt und die Genome repliziert werden. Je nach der Art des Genoms gibt es hierfür verschiedene Mechanismen.

D Viren mit einem RNA-Genom in Positivstrang-Orientierung verwenden dieses als mRNA für die Translation viraler Proteine.

Viren mit einem einzelsträngigen RNA-Genom in Positivstrang-Orientierung (•Tabelle 10.1), verwenden dieses als mRNA und starten direkt nach der Freisetzung der Nucleinsäure in das Cytoplasma die Translation (Ausnahme: Retroviren). Da die mRNA-Genome der PositivstrangRNA-Viren nur eine begrenzte Anzahl von RibosomenBindungsstellen enthalten, sind die meisten gezwungen, die in ihrem Genom verankerten Informationen als Polyproteine zu synthetisieren. Diese Vorläuferprodukte, die beispielsweise bei den Polioviren die Sequenzen aller elf Virusproteine enthalten, werden z.T. noch während der Translation durch viruseigene Proteasen in ihre Einzelproteine zerschnitten.

Das mRNA-Genom dieser Viren codiert u.a. für eine RNA-abhängige RNA-Polymerase. Diese übersetzt das mRNA-Genom in einen dazu komplementären Negativstrang, welcher als Matrize für die Synthese neuer Virusgenome dient.

C Viren mit einem RNA-Genom in Negativstrang-Orientierung besitzen eine RNA-abhängige RNA-Polymerase als Bestandteil der Partikel.

Im Unterschied hierzu ist es für alle Viren mit einzelsträngigen RNA-Genomen in Negativstrang-Orientierung - unabhängig davon, ob sie in Segmenten oder als kontinuier- liche Nucleinsäure vorliegen - notwendig, im ersten Schritt des Infektionszyklus diese in mRNAs umzuschreiben. Das dafür notwendige Enzym, die RNA-abhängige RNAPolymerase, ist bei diesen Viren ein Strukturbestandteil der Nucleocapside und wird mit in die infizierte Zelle hineingebracht. Von den auf diese Weise erzeugten mRNAs werden dann die entsprechenden Virusproteine translatiert. Polyproteine werden nicht gebildet. Influenza- und Bornaviren, die ihre Nucleocapside in den Kern transportieren, können hier auf die Zellfunktionen zum mRNASpleißen zurückgreifen und produzieren auch alternativ gespleißte Transkripte, wodurch die begrenzte Codierungskapazität dieser Infektionserreger erweitert wird. Eine alternative Methode dazu haben die Paramyxoviren entwickelt: Sie fügen posttranskriptionell an bestimmten Positionen der mRNA, die für die Synthese eines RNAbindenden Phosphoproteins (P-Protein) verantwortlich sind, ein bis zwei Guanosinreste ein. Diesen Vorgang bezeichnet man als RNA-Editing ( $\checkmark$ Kapitel 8.5.4). Dadurch erfolgt ab diesen Punkten die Translation in unterschiedlichen Leserastern, es entstehen Proteine mit neuen Funktionen.

Ein durchgehender, zum Genom komplementärer RNA-Strang dient als Matrize für die Replikation der Virusgenome. Bei den Vertretern der Negativstrang-RNA-Viren mit segmentierten RNA-Genomen (Orthomyxo-, Bunya-, und Arena-Viren) wird mit jedem einzelnen Genomsegment in analoger Weise verfahren.

(C)

Bei Viren mit einem doppelsträngigen RNA-Genom codiert nur ein Strang für die viralen Genprodukte.

Die Reoviren besitzen als einzige Virusfamilie ein doppelsträngiges, in Segmenten vorliegendes RNA-Genom. Auch bei ihnen findet man als Teil der Viruspartikel eine RNA-abhängige RNA-Polymerase. Sie gelangt bei der Infektion in die Zelle und transkribiert die Negativstränge der RNA-Segmente. Die entstehenden mRNAs dienen zur Translation der verschiedenen Virusproteine und zugleich auch als Matrizen für die Synthese neuer Doppelstränge. Damit ist in den neu synthetisierten RNADoppelsträngen keiner der Elternstränge vorhanden: Es handelt sich also um einen konservativen Replikationsmechanismus.

D Die Funktion der reversen Transkriptase ist für die Replikation der Retro- und der Hepadnaviren notwendig.

Die Retroviren und die Hepadnaviren enthalten als Teil der Nucleocapside (• Abb. 10.3, 10.7) eine reverse Transkriptase, welche bei der Infektion mit in die Zelle gelangt (• Abb. 10.4). Die RNA-abhängige DNA-Polymeraseaktivität dieses Enzyms katalysiert bei den Retroviren unter Verwendung des mRNA-Genoms als Matrize die Umschreibung in doppelsträngige DNA, die in das Zellgenom integriert wird. Diesen Prozess steuert eine virale Integrase, die 


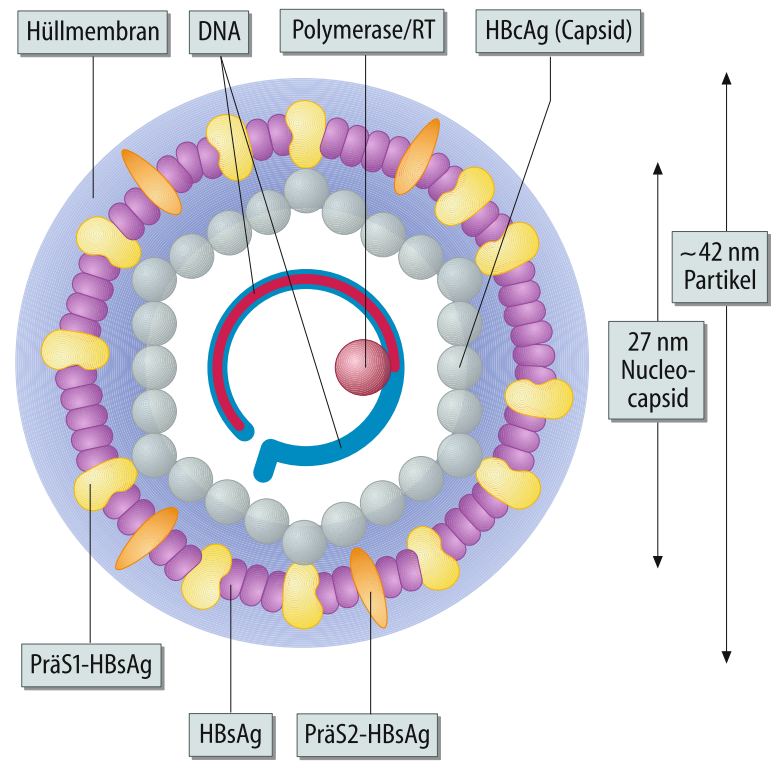

- Abb. 10.7. Aufbau eines Hepatitis-B-Virus. Das Capsid des Virus, das aus dem Protein HBcAg besteht, ist von einer Membranhülle umgeben, in welche die viralen Oberflächenproteine (HBsAg, PräS1$\mathrm{HBsAg}$, PräS2-HBsAg) eingelagert sind. Im Inneren befindet sich das virale Genom, das aus einer teilweise doppelsträngigen DNA in zirkulärer Form besteht. An das Genom assoziiert ist die reverse Transkriptase (Polymerase/RT)

ebenfalls als Teil der Nucleocapside aufgenommen wird. Die integrierte Virus-DNA, das sog. Provirus, verhält sich wie ein gewöhnliches Zellgen und wird bei Teilung mit dem Zellgenom vermehrt und an die Tochterzellen weitergegeben. Transkription und Translation der Virusgene finden nur von der Provirus-DNA statt. Die Transkription wird von der RNA-Polymerase II der Zelle katalysiert; es entstehen bei allen Retroviren gespleißte und ungespleißte mRNAs. Bei den Lentiviren und somit auch bei den humanen Immundefizienzviren erfolgt zusätzlich die Synthese mehrfach gespleißter mRNAs, aus denen verschiedene regulatorisch aktive Proteine gebildet werden (• Abb. 10.4, 10.8; - Tabelle 10.3). Die ungespleißte, die gesamte Länge des Provirus überspannende mRNA, wird für die Synthese der Vorläuferproteine und für die Produktion der gruppenspezifischen Antigene Gag und Gagpol verwendet sowie als virales Genom direkt in die Partikel verpackt. Von der einfach gespleißten mRNA werden die viralen Membranproteine translatiert.

D Viren mit DNA-Genomen transportieren diese in den Zellkern, wo die Transkription erfolgt.

Hepadnaviren. Die Hepadnaviren und mit ihnen die Hepatitis-B-Viren stehen den Retroviren evolutionsgeschichtlich sehr nahe. Ihr teilweise doppelsträngiges DNA-Genom (• Abb. 10.7, 10.9) wird nach der Freisetzung der Nucleinsäure durch die DNA-abhängige DNA-Polymerase-Aktivität der mit der Erbinformation assoziierten

\begin{tabular}{|c|c|c|c|}
\hline Gen & & Molgewicht & Funktion \\
\hline \multicolumn{4}{|c|}{ Strukturgene } \\
\hline \multirow[t]{4}{*}{ GAG: } & MA & $\mathrm{p} 17$ & $\begin{array}{l}\text { Matrixprotein } \\
\text { Interaktion mit Hüll- bzw. Plasma- } \\
\text { membran }\end{array}$ \\
\hline & $C A$ & $\mathrm{p} 24$ & Capsid-Protein \\
\hline & NC & p 9 & Nucleocapsid \\
\hline & & p 6 & Link-Protein \\
\hline \multirow[t]{3}{*}{ POL: } & PR & p 10 & Protease \\
\hline & RT & p 66/51 & Reverse Transkriptase \\
\hline & IN & p 34 & Integrase (Provirus-Bildung) \\
\hline ENV: & EP & gp 120 & $\begin{array}{l}\text { Externes Glycoprotein, Rezeptor- } \\
\text { bindung }\end{array}$ \\
\hline & TM & gp 41 & $\begin{array}{l}\text { Transmembranäres Glycoprotein, } \\
\text { Membranfusion }\end{array}$ \\
\hline
\end{tabular}

\section{Regulatorgene}

TAT

Regulation der Genexpression (Transaktivator der Transkription)

REV

Regulation des mRNA-Transports von einfach und ungespleißten Transkripten

TEV

TAT ähnliche Funktion

NEF

Aufrechterhaltung der Virusverbreitung

VPR

Noch unbekannt

\section{Zusatzgene}

VIF

ENV-Prozessierung und Konformation

VPU

Virusreifung und -freisetzung

$p$ Protein; gp Glycoprotein; Zahlen geben die Molekülmasse in kDa wieder.

reversen Transkriptase vervollständigt und als zirkulär geschlossene, doppelsträngige DNA in den Zellkern transportiert.

Durch die zelluläre RNA-Polymerase II werden verschiedene mRNAs transkribiert (- Abb. 10.9). Ein Transkript überspannt auch hier die gesamte Genomlänge, wobei die Enden sogar miteinander überlappen. Dieses wird für die Synthese der Capsidproteine und der reversen Transkriptase eingesetzt. Letztere schreibt auch die überlangen Transkripte in doppelsträngige DNA um und ist damit für die Synthese der Hepadnavirus-Genome verantwortlich.

Doppelsträngige DNA-Viren. Für die Transkription und die Translation werden entsprechende Enzyme der Wirtszelle benötigt. Eine Ausnahme bilden die Pockenviren, die in ihrem Genom für virale RNA-Polymerasen codieren und deswegen auf die zellulären Enzyme verzichten können. Sie transkribieren ihr Genom im Cytoplasma. 


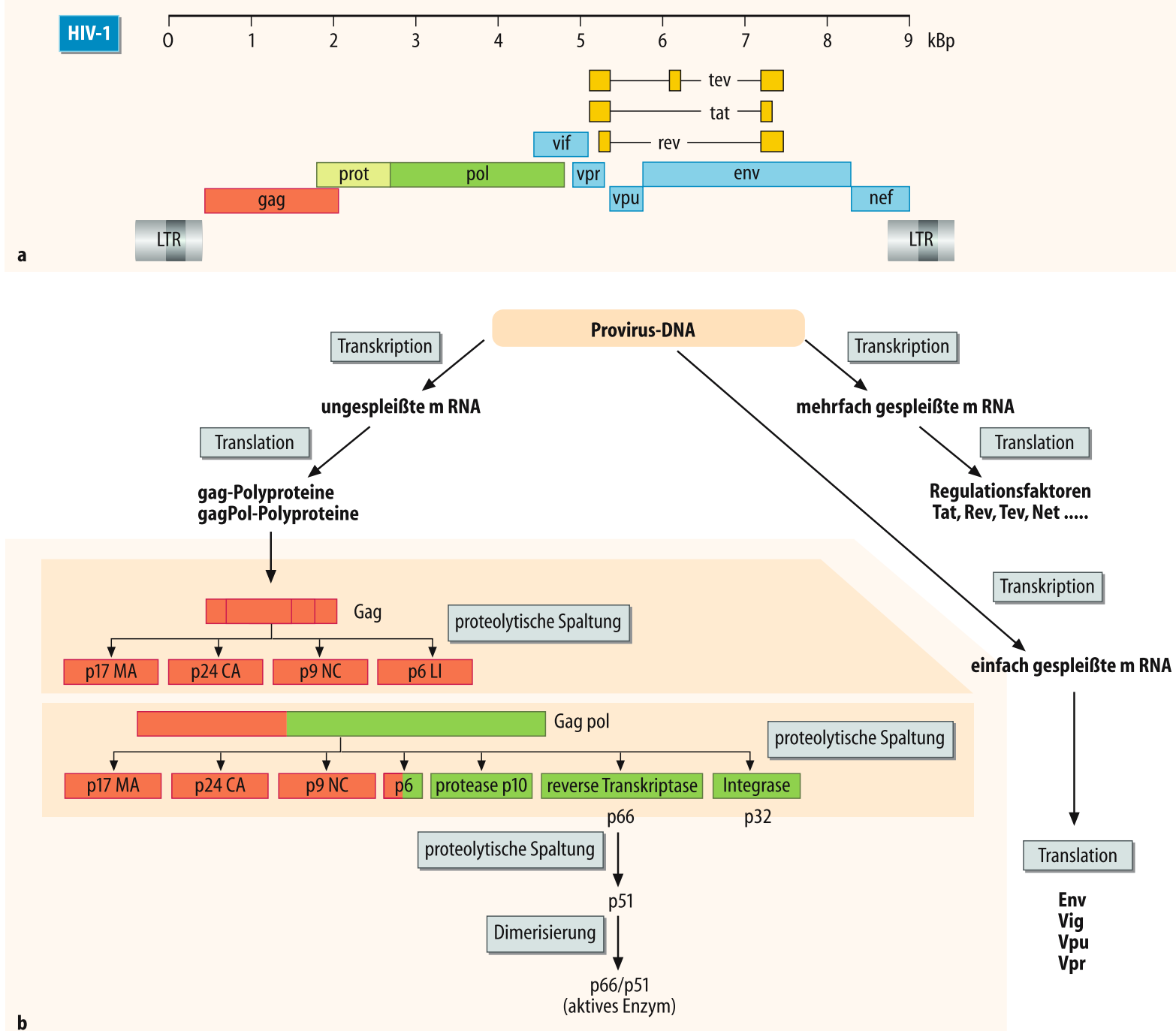

- Abb. 10.8. Genom-Organisation und Genexpression des humanen Immundefizienzvirus. a Das nach Umschreiben in doppelsträngige DNA entstandene und in das Wirtsgenom integrierte Genom des HIV-Provirus enthält neben den beiden flankierenden long terminal repeats (LTR) 10, sich teilweise überlappende Gene (• Tabelle 10.3).

Mit Ausnahme der Polyomaviren codieren Viren mit doppelsträngigem DNA-Genom für eigene DNA-Polymerasen. Während sich bei den Adenoviren der Replikationsursprung an den Enden des linearen Genoms befindet und die DNA-Synthese durch Verwendung eines viralen Proteins, des sog. terminalen Proteins, als Primer initiiert wird, wird bei den Herpesviren das lineare Genom im ersten Schritt der Infektion zirkulär geschlossen. Es dient der Synthese der viralen DNA-Polymerase und anderer an der Replikation beteiligter Nichtstrukturproteine und Enzyme, welche die Virusgenome vervielfältigen. Die Polyoma- und Papillomviren replizieren ihr zirkuläres DNA-Genom, ausgehend von einem Initiationspunkt bidirektional nach b Unter dem Einfluss des zellulären Transkriptionsfaktors NF-kB werden diese transkribiert und die entstehende RNA unterschiedlich gespleißt. Durch Translation entstehen neben den Regulationsfaktoren die Polyproteine Gag, Gagpol und Env. Diese werden durch die HIV-Protease in die viralen Strukturproteine und Enzyme gespalten (• Abb. 10.3)

einem Mechanismus, welcher demjenigen der Replikation von ringförmiger Bakterien-DNA ähnelt ( $\downarrow$ Kapitel 7.2.2).

Einzelsträngige DNA-Viren. Die Parvo- und die Circoviren verfügen über keine eigene DNA-Polymerase. Sie verwenden für die Genomreplikation zelluläre Enzyme, die in ihrer Funktion modifiziert werden. Es entstehen doppelsträngige DNA-Intermediate, die anschließend wieder in Einzelstränge umgeschrieben werden. 


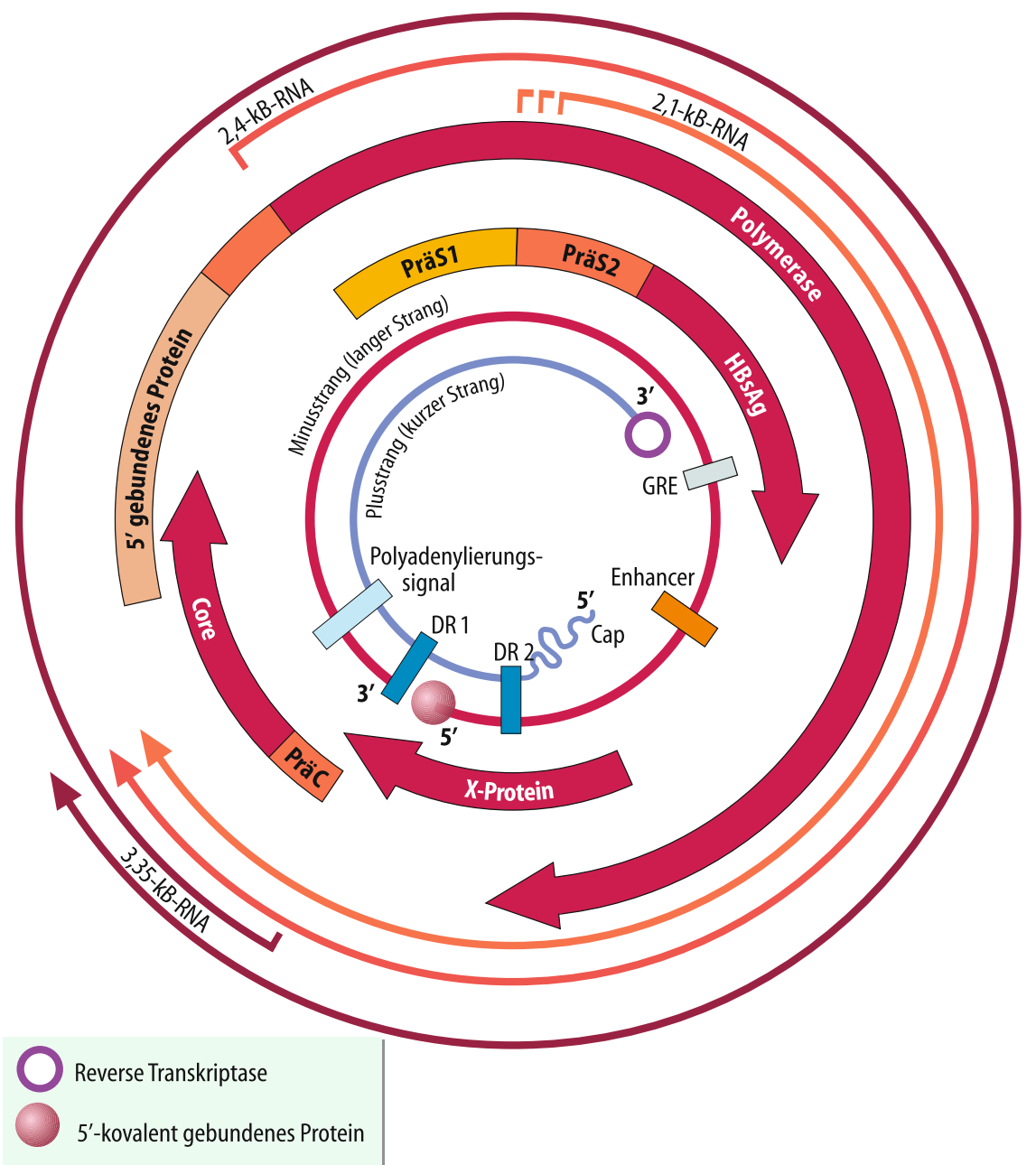

- Abb. 10.9. Organisation des Genoms des Hepatitis-B-Virus. Das Genom besteht aus einer teilweise doppelsträngigen DNA. Am 5 '-Ende des vollständigen Minus-Strangs ist ein terminales Protein gebunden, am 3'-Ende des unvollständigen Plusstranges die reverse Transkriptase. Das Genom enthält vier offene Leserahmen (dicke Pfeile), die für die Synthese der Capsidproteine ( $\mathrm{HBCAg})$, der Oberflächenproteine (HBsAG, P PräS1-HBsAg, PräS2-HBsAg), der enzyma-

\subsubsection{Regulation der viralen Gen- expression und Replikation}

D Die Synthese der viralen Enzyme und Regulatorproteine findet früh während des Infektionszyklus statt.

Die im Verlauf des Infektionszyklus produzierten Virusproteine lassen sich in zwei Gruppen mit grundsätzlich verschiedenen Funktionen einteilen:

- Strukturproteine, die man als Bestandteile der infektiösen Viruspartikel findet, und

- Nichtstrukturproteine, die sich in solche mit enzymatischen und solche mit regulatorischen Funktionen aufteilen lassen tischen Funktionen (Reverse Transkriptase $=$ Polymerase, $5^{\prime}$-bindendes Protein) und des X-Proteins, welches regulatorische Funktionen hat, codieren. Die dünnen äußeren Pfeile geben die bis jetzt identifizierten mRNAs wieder, die als Matrize für die Translation der viralen Proteine dienen. DR1 und DR2 = repetitive Sequenzen; GRE = glucocorticoid response element

Die Enzyme sind für die Schritte im Infektionszyklus verantwortlich, bei denen die Viren nicht auf entsprechende Zellfunktionen zurückgreifen können. Sie sind v.a. bei der Replikation der Virusgenome aktiv. Dazu zählen vorrangig:

- RNA-abhängige RNA-Polymerasen. Alle RNA-Viren mit Ausnahme der Retroviren schreiben während des Infektionszyklus ihr RNA-Genom in dazu komplementäre RNA-Moleküle um. Diesen Vorgang gibt es in eukaryotischen Zellen nicht. Folglich ist das Gen zur Synthese der RNA-abhängigen RNA-Polymerase im Virusgenom vorhanden und wird in den infizierten Zellen exprimiert

- RNA-abhängige DNA-Polymerasen (reverse Transkriptase). Dieses Enzym findet man bei den Retro- 
viren und den Hepadnaviren. Es kehrt den in der Molekularbiologie üblichen Informationsfluss von DNA über RNA zu Protein um. Retroviren schreiben mit diesem Enzym ihr mRNA-Genom in doppelsträngige DNA um, welche sie dann ins Genom der Wirtszelle integrieren

- DNA-Polymerasen. Insbesondere die komplexen Viren mit einem großen DNA-Genom (beispielsweise die Adeno-, Herpes- und Pockenviren) haben für die Replikation ihrer Erbinformation Mechanismen entwickelt, die sich von den Prozessen der DNA-Replikation der Zelle unterscheiden. Sie verwenden für die Genomreplikation eigene DNA-Polymerasen

- Proteasen. Die Positivstrang-RNA-Viren und die Retroviren synthetisieren die in ihrem Genom verankerte Information nicht in der Form einzelner, voneinander getrennter Proteine, sondern als Polyproteine. Diese werden durch proteolytische Spaltung in die verschiedenen funktionell aktiven Einheiten zerteilt (• Abb. 10.4, 10.8). Für diesen Vorgang verwenden die Viren überwiegend eigene Proteasen, die Teil der Polyproteine sind und im ersten Schritt autokatalytisch aktiv werden

( Die viralen Replikationsenzyme haben eine wesentlich höhere Fehlerquote als diejenigen der Wirtszellen.

Die meisten Viren haben für die Replikation ihrer Erbinformation eigene, von zellulären Prozessen weitgehend unabhängige Strategien entwickelt. Zelluläre DNA-Polymerasen verwenden nur die kleinen DNA-Viren, die Polyoma-, die Parvo- und die Circoviren. Deswegen sind die Vertreter dieser Virusfamilien im Unterschied zu allen anderen auch genetisch relativ stabil. Variationen in den Nucleotidsequenzen findet man hier nur begrenzt. Alle anderen Viren sind bei den Replikationsstrategien auf virale Enzyme angewiesen (• Abschnitt 10.2.4). Während die DNA-Polymerasen der Zelle über Aktivitäten wie die 3'-5'-Exonuclease zur Überprüfung der Lesegenauigkeit verfügen und die Synthese der komplementären DNA-Stränge mit großer Präzision durchführen ( Kap. 7.2.3) - die Fehlerwahrscheinlichkeit liegt bei etwa $10^{-9}$ - arbeiten die viralen Enzyme wesentlich ungenauer. Bei einigen Viren wie den Hepatitis-C-Viren oder den Humanen Immundefizienzviren ist etwa jede 1000 . bis 10000 . Base nicht komplementär zur Sequenz des Ausgangsstrangs, jedes neu synthetisierte Genom enthält daher durchschnittlich eine bis zehn Mutationen. Auch wenn diese die Infektiosität vieler Nachkommenviren beeinträchtigen, ist die hohe Variabilität für die Bildung der verschiedenen Subtypen und der großen Zahl von Quasispezies, die man v.a. bei diesen Viren findet, verantwortlich.

( Die Genexpression der Viren ist streng reguliert und an die Wirtszelle angepasst.

Die virale Genexpression stellt erhebliche regulatorische Anforderungen:
- Die wirtszelleigene Genexpressions-Maschinerie soll möglichst abgeschaltet und vollständig in den Dienst der Produktion neuer Viren gestellt werden

- Die Biosynthese viraler Proteine muss an die Bedürfnisse der Viren angepasst werden. Von den Strukturproteinen als Hauptbestandteilen der Nachkommenviren benötigen sie beispielsweise viele Einheiten, wohingegen bei den Enzymen meist einige wenige Moleküle genügen

Insbesondere die komplexen Viren regulieren daher ihre Genexpression über unterschiedliche positive und negative Regulatoren und Transkriptionsfaktoren. Auch greifen sie in die Stoffwechselprozesse der Zellen ein und verhindern auf verschiedenste Weise die zelluläre Transkription und Translation.

Zusätzlich zur Regulation der Syntheserate der viralen Genprodukte ist es insbesondere für die komplexen DNAViren wichtig, die Produktion der Nichtstrukturproteine und Enzyme zeitlich von derjenigen der Strukturproteine abzutrennen. Die Polymerasen zur Vervielfältigung der Virusgenome müssen relativ früh im Infektionszyklus gebildet werden. Jedoch ist auch ihre Synthese oft von bereits zuvor produzierten viralen Transkriptionsfaktoren abhängig. Bei diesen Viren unterliegt die Genexpression einer kaskadenartigen Regulation, die sich grob in folgende Abschnitte einteilen lässt:

- Synthese der frühen Regulatorproteine und Transkriptionsfaktoren

- Synthese der Enzyme und weiterer früher Nichtstrukturproteine. Sie wird oft durch die Aktivität der sehr frühen Regulatorproteine eingeleitet und ist von ihrer Funktion abhängig

- Vervielfältigung der Virusgenome

- Synthese der Strukturproteine

\subsubsection{Morphogenese}

(D) Der Zusammenbau der Virusproteine und Genome zu infektiösen Viruspartikeln erfolgt durch Selbst-Organisation (self-assembly) und ist weitgehend unabhängig von zellulären Funktionen.

Nach der Replikation liegen in der Zelle sowohl die viralen Strukturproteine als auch die jeweiligen Genome in vielfachen Kopien vor. Diese lagern sich zu Nucleocapsiden, Capsiden und schließlich infektiösen Viren zusammen. Bei allen membranumhüllten und auch bei den meisten anderen Viren findet der Zusammenbau an Membranen der Wirtszelle statt. Diese stellen den Infektionserregern auch ihre Membranhülle zur Verfügung. So nutzen beispielsweise die Retro-, Rhabdo-, Para- und Orthomyxoviren die Plasmamembran als Ort für die Morphogenese (• Abb. 10.4), wohingegen die Bildung der Flavi-, Toga-, Arena- 


\section{Infobox \\ Ungenauigkeiten beim Zusammenbau der Viren mit segmentierten RNA-Genomen können die Bildung von neuen Virustypen bewirken.}

Besonders kompliziert erscheint der Zusammenbau der verschiedenen Komponenten bei den Viren, deren Genom in Segmente unterteilt ist, wie beispielsweise bei den Influenza-A-Viren, den Erregern der klassischen Virusgrippe. Ihr Genom liegt in acht Segmenten vor, von denen ein jedes für die Synthese von ein bis zwei speziellen Virusproteinen verantwortlich ist. Die Nachkommenviren müssen folglich von jedem Segment mindestens eine Kopie in den Partikeln verpacken. Es gibt dafür jedoch keinen speziellen Mechanismus. Untersucht man die Influenza-A-Viren hinsichtlich ihres Gehalts an RNASegmenten, dann findet man anstatt der acht meist 11 bis 14 Genomabschnitte. Die Viren nehmen beim Zusammenbau immer so viele RNA-Segmente in die neu gebildeten Partikel auf, wie es deren Morphologie zulässt. Damit erhöhen sie die Wahrscheinlichkeit, dass jeweils einer der acht unterschiedlichen Abschnitte verpackt wird. Jedoch findet man trotz dieses Tricks viele nicht infektiöse Influenza-A-Viren in der Population der Nachkommenviren. Die Erreger kompensieren dies durch die große Menge der produzierten Nachkommen.

Dieser relativ einfache Verpackungsmodus der RNASegmente erklärt auch die Entstehung neuer Influenzavi- ren, welche Pandemien hervorrufen. Diese zeichnen sich durch das Auftreten von Influenzaviren aus, welche auch die Menschen infizieren, die bereits in einer der vorangegangenen Pandemien eine Influenza überstanden und in ihrem Verlauf eine schützende Immunantwort ausgebildet hatten. Derartige Pandemien ereigneten sich während des letzten Jahrhunderts in Abständen von etwa 10 bis 20 Jahren und waren durch das Auftreten von solchen Influenza-A-Viren gekennzeichnet, deren Oberflächenproteine Hämagglutinin und Neuraminidase bis zu diesen Zeitpunkt nur bei tierpathogenen InfluenzaA-Viren gefunden wurden. Die Entstehung derart neuer Virustypen kommt durch die gleichzeitige Infektion eines Wirtes mit unterschiedlichen tier- und humanpathogenen Influenza-A-Virus-Typen zustande. Als ein solcher Wirt gilt das Schwein, das sowohl für Infektionen mit GeflügelInfluenza-A-Viren wie auch mit humanpathogenen Virustypen empfänglich ist. Bei gelegentlich auftretenden Doppelinfektionen erfolgt bei der Morphogenese auch die zufällige Verpackung der Segmente von den unterschiedlichen Viren. In seltenen Fällen entsteht im Verlauf dieses Reassortments (phenotypic mixing) eine Variante der Influenza-A-Viren mit immunologisch neuen Eigenschaften der Oberflächenproteine (antigenic shift), gegen welche in der menschlichen Bevölkerung kein Immunschutz vorliegt und die sich deshalb effizient und schnell verbreiten kann (• Abb. 10.10). und Hepadnaviren an der Membran des endoplasmatischen Retikulums stattfindet. Die Bunyaviren verwenden die Membran der Golgi-Vesikel und die Herpesviren die innere Kernmembran.

Viele Vorgänge bei der Virusmorphogenese sind noch nicht endgültig geklärt. Zelluläre Proteine, etwa Chaperone, können den Zusammenbau der Komponenten beeinflussen. So ist beispielsweise in den Virionen des $\mathrm{Hu}-$ manen Immundefizienzvirus Typ1 das Chaperon Cyclophilin, eine Peptidyl-Prolyl-cis-trans-Isomerase, enthalten ( Kap. 9.2.1). Ob seine Aktivität für die Infektiosität der Viren wichtig ist, ist nicht endgültig geklärt.

\subsubsection{Freisetzung der Nachkommenviren}

D Die Freisetzung der infektiösen Nachkommenviren aus den infizierten Zellen ist für die Verbreitung der Erreger essentiell.

Knospung. Ein Weg zur Freisetzung der Viren aus den Wirtszellen ist die Knospung (budding). Er ist an die Orte gebunden, an denen auch die Morphogenese abläuft. So knospen die Viren, die sich an der Plasmamembran zusammenlagern, von der Zelloberfläche (• Abb. 10.11).
Sekretion. Viren, die sich an den Membranen des endoplasmatischen Retikulums oder der Golgi-Vesikel assemblieren, schnüren ihre Partikel in das Lumen dieser Organellen $\mathrm{ab}$ und werden im weiteren Verlauf über die GolgiVesikel zur Zelloberfläche transportiert und dort gleichsam in die Umgebung sezerniert.

Zelltod. Eine andere Möglichkeit der Virusfreisetzung ist mit dem Absterben der infizierten Zellen verbunden. Viele Erreger schädigen ihre Wirtszelle im Infektionsverlauf so stark, dass sie nicht mehr lebensfähig ist. Dies geschieht nicht nur durch die parasitäre Lebensweise der Viren, sondern auch durch den sog. virus-host-shut-off. Hierbei greifen die Viren mit bestimmten Proteinen in die Stoffwechselprozesse der Zelle ein und steuern diese zu ihren Gunsten um. Die infizierten Zellen versuchen diesen Vorgängen häufig durch Einleitung der Apoptose, des programmierten Zelltods ( Kap. 7.1.5) zuvorzukommen.

Um die effiziente Freisetzung der Nachkommenviren und die schnelle Ausbreitung der Infektion im Gewebe zu erleichtern, verfügen einige Viren wie die Paramyxoviren (Parainfluenza- oder Mumpsviren) oder die Orthomyxoviren (Influenzaviren) über Rezeptor-zerstörende Eigenschaften. Diese Viren binden sich mittels ihres Oberflächenproteins Hämagglutinin (HA) an N-Acetyl-Neura- 


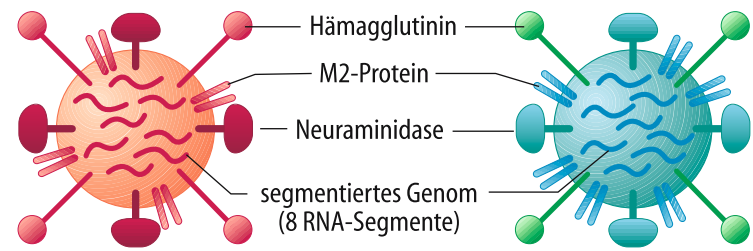

Vogelinfluenzavirus

a

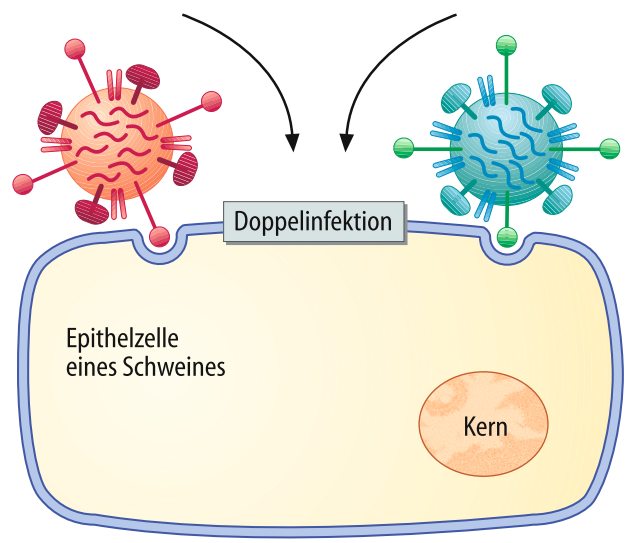

b
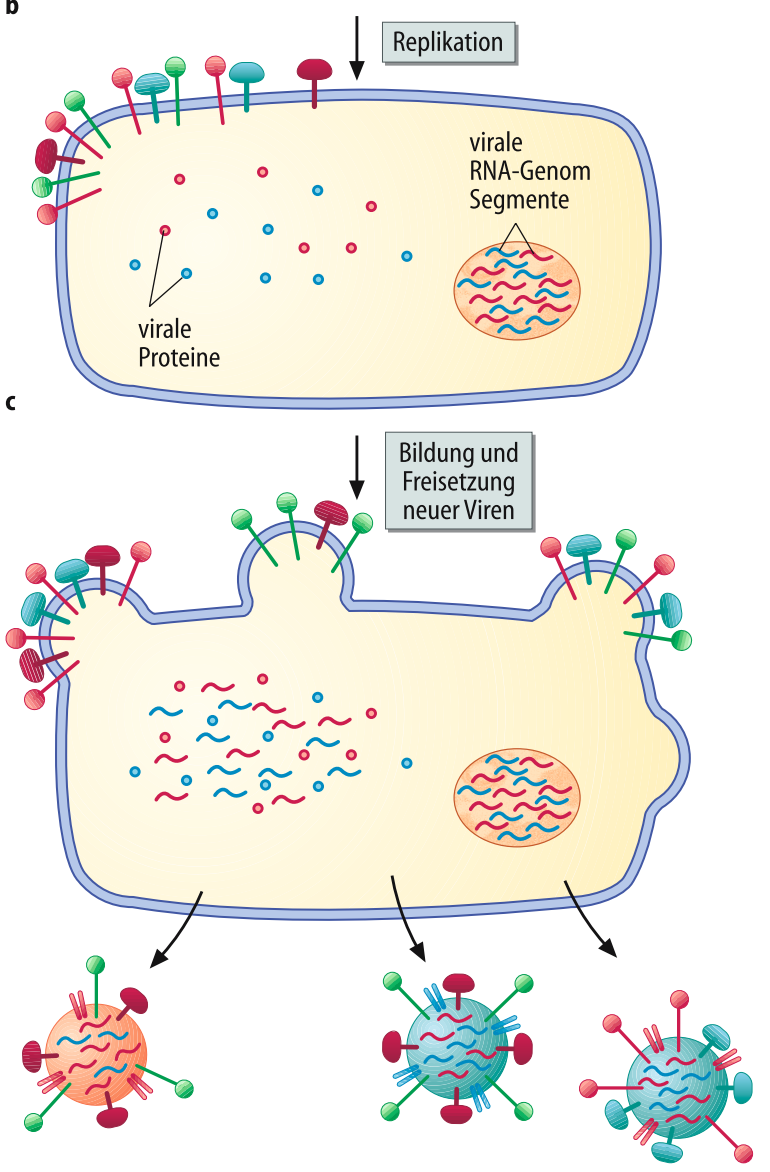

Austausch der Oberflächenproteine Hämagglutinin/Neuraminidase durch Neukombination der Genomsegmente $=>$ Bildung von Viren mit neuen Eigenschaften und veränderter Infektiosität
- Abb. 10.10a-d. Bildung von Influenzaviren mit neuen Eigenschaften durch reassortment der Genomsegmente. Influenzaviren haben ein segmentiertes Genom, das aus acht Segmenten einzelsträngiger RNA besteht, die von einer Hüllmembran umschlossen sind. In die Hüllmembran sind die viralen Oberflächenproteine (Hämagglutinin, Neuraminidase und das M2-Protein) eingelagert. a Es existieren verschiedene Influenzavirus-Typen, die Vögel (Enten, Möwen, etc. rot), Säugetiere (Schweine, Pferde) oder Menschen (türkis) infizieren können. Gewöhnlich sind die Viren spezifisch, das heißt, Vogelinfluenzaviren können Menschen nicht infizieren und umgekehrt. b Schweine sind jedoch sowohl für verschiedene Vogelinfluenzaviren wie auch für humane Influenzaviren empfänglich. Bei der Infektion eines Schweines mit beiden Virusarten können die Epithelzellen des Tieren doppelt infiziert werden. Dabei binden sich die Viren über das Hämagglutinin an Acetylneuraminsäure-haltige Kohlenhydratstrukturen auf der Zelloberfläche. c Die Viren vermehren ihre Genomsegmente im Kern der infizierten Zelle und produzieren virale Proteine. Dabei kommt es zur Vermischung der Genomsegmente und der Proteine von aviären und humanen Influenzaviren. d Deshalb werden bei der Virusmorphogenese Mixturen an unterschiedlichen Genomsegmenten in die von der Zelloberfläche freigesetzten Nachkommenviren verpackt. So können neue Viren entstehen, die neue Eigenschaften (Hämagglutinin- und Neuraminidasetypen) haben und gegen die in der menschlichen Bevölkerung kein Immunschutz besteht

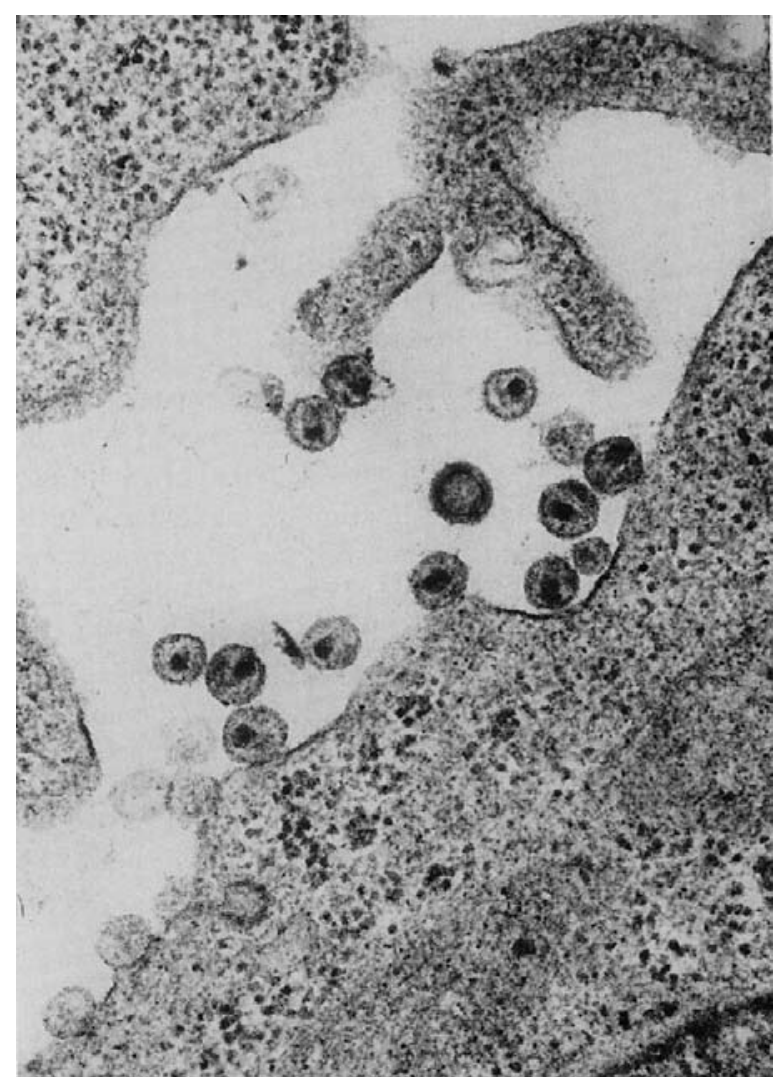

- Abb. 10.11. Freisetzung der Nachkommenviren durch Knospung. Gezeigt ist eine elektronenmikroskopische Aufnahme von HIV-infizierten T-Lymhozyten (Aufnahme von H. Frank, Tübingen, aus Kulturen von H. Kurth, Frankfurt). Vergr. 66000:1 
minsäure (Sialinsäure), die sich als endständige Kohlenhydrateinheit an zellulären Glycoproteinen befindet (•Tabelle 10.2). Zugleich verfügen diese Viren über eine Neuraminidase-Aktivität (NA), welche die Sialinsäurereste der Glycoproteine abspaltet. Dieses virale Enzym entfaltet seine Aktivität während der Infektion in der Zelle und entfernt die endständigen Neuraminsäurereste von allen zellulären und viralen Proteinen. So ist gewährleistet, dass die neu gebildeten Nachkommenviren nicht miteinander oder mit den Oberflächenstrukturen ihrer geschädigten Wirtszellen wechselwirken. Dies würde die

\section{In Kürze}

Die Vorgänge bei der Virusvermehrung lassen sich in sieben Abschnitte gliedern:

Adsorption. Durch sie erfolgt die Bindung der Viruspartikel an bestimmte Oberflächenkomponenten (zelluläre Membranproteine oder Kohlenhydratstrukturen) ihrer Zielzellen. Dieser Vorgang bestimmt meist die Zell- und Wirtsspezifität der Viren.

Aufnahme der Viruspartikel. Sie kann je nach Virustyp durch rezeptorvermittelte Endozytose oder durch Fusion der Plasmamembran mit der Virushüllmembran erfolgen.

Freisetzung der viralen Erbinformation aus dem Nucleocapsid (uncoating)

Expression der Virusgene. Je nachdem, ob die Viren über RNA- oder DNA-Genome, in einzelsträngiger oder
Ausbreitung der Infektion entscheidend hemmen ( $\triangleright$ Kapitel 10.5.2).

Rezeptor-zerstörende Funktionen findet man auch bei anderen Viren: Beispielsweise bilden die Humanen Immundefizienzviren ein Zusatzprotein Vpu (viral protein out), das an die cytoplasmatische Domäne des CD4Proteins bindet, welches von diesen Viren als zellulärer Rezeptor genutzt wird (•Tabelle 10.3, • Abb. 10.4). Die Interaktion beider Proteine veranlasst die Ubiquitinylierung des CD4-Rezeptors und seinen Abbau über die Proteasomen.

doppelsträngiger Form, in Negativ- oder Positivstrangorientierung verfügen, verwenden sie hierfür spezielle Verfahrensweisen. Die dabei produzierten Virusproteine lassen sich in Strukturproteine und in Nichtstrukturproteine mit enzymatischen und regulatorischen Funktionen einteilen.

Replikation des Virusgenoms. Sie ist meist von der Aktivität bestimmter Enzyme als Teil der viralen Nichtstrukturproteine (Polymerasen, Proteasen) abhängig.

Aufbau der Nachkommenviren. Diese werden aus den neu gebildeten Genomen und den Strukturproteinen im einem self-assembly-Prozess zusammengebaut.

Freisetzung. Die Nachkommenviren werden durch Knospung (budding) von der Zelloberfläche abgegeben oder nach dem Absterben der Zelle durch Apoptose oder Nekrose in die Umgebung freigesetzt.

\subsection{Folgen der Virusinfektion für Wirtszelle und Wirtsorganismus}

\subsubsection{Zellschädigung und Viruspersistenz}

(8) Abhängig vom Erregertyp können Virusinfektionen für die Zellen und die Wirte unterschiedliche Folgen haben.

Zellzerstörung und Apoptose. Infolge einer Virusinfektion kann die infizierte Zelle zerstört werden und absterben. Hierfür können direkte Wirkungen der Virusproteine ( $v i$ rus-host-shut-off-Faktoren) ebenso verantwortlich sein wie die indirekte Einflussnahme des infizierten Wirtsorganismus. Dieser aktiviert im Infektionsverlauf eine Vielzahl von unspezifischen und spezifischen immunologischen Abwehrmechanismen, welche sowohl die Krankheitserreger selbst wie auch die von ihnen infizierten Zellen bekämpfen ( $\triangleright$ Kap. 34). Häufig kommt es dadurch zur Nekrose mit Zellschwellung, Verlust der Membran-Integri- tät und späterem Abbau der DNA ( $\vee$ Kap. 7.1.5). Alternativ hierzu kann die infizierte Zelle den Prozess der Apoptose einleiten ( $\triangleright$ Kapitel 7.1.5). Dieser Vorgang kann auch als eine Art der Abwehrreaktion des Organismus angesehen werden, mit welcher dieser versucht, den durch die Virusreplikation bedingten Schaden zu begrenzen.

Virusinfektionen, die mit massiven Zellschädigungen und damit auch mit tödlichen Folgen für den Organismus verbunden sind, sind bei immunologisch gesunden Wirten relativ selten. Derartige Infektionsverläufe ereignen sich bevorzugt in immunologisch nicht kompetenten Wirten (Neugeborene, Transplantationspatienten, HIV-Patienten, Patienten mit erblichen Störungen des Immunsystems) oder in den Fällen, in denen ein üblicherweise tierpathogenes Virus auf den Menschen übertragen wird. Ein Beispiel dafür sind die Infektionen mit den Marburg- und Ebolaviren, die als natürliche Wirte noch nicht bekannte Wildtiere infizieren. Werden diese Viren durch Kontakt mit den infizierten Tieren auf Menschen übertragen, dann treten häufig die Symptome eines tödlichen hämorrhagischen Fiebers auf. 


\begin{tabular}{|c|c|c|c|}
\hline Virus & Erstinfektion & $\begin{array}{l}\text { Symptome } \\
\text { bei Persistenz }\end{array}$ & Latenz \\
\hline Hepatitis-C-Virus & Leberentzündung & $\begin{array}{l}\text { Leberzirrhose } \\
\text { Leberzellkarzinom }\end{array}$ & \\
\hline Hepatitis-G-Virus & $?$ & $?$ & \\
\hline Masernvirus & Masern & $\begin{array}{l}\text { subakute, sklerosierende } \\
\text { Panenzephalitis (SSPE) }\end{array}$ & \\
\hline $\begin{array}{l}\text { Humanes Immun- } \\
\text { defizienzvirus (HIV) }\end{array}$ & Fieber, Lymphknotenschwellung & Immundefizienz & \\
\hline $\begin{array}{l}\text { Humanes T-Zell } \\
\text { Leukämie-Virus (HTLV-1) }\end{array}$ & $?$ & & $\begin{array}{l}\text { adulte T-Zell Leukämie, trophisch- } \\
\text { spastische Paraparese }\end{array}$ \\
\hline Hepatitis-B-Virus & Leberentzündung & $\begin{array}{l}\text { Leberzirrhose } \\
\text { Leberzellkarzinom }\end{array}$ & \\
\hline Papillomviren & Warzen, Hautläsionen & Warzen, Hautläsionen & $\begin{array}{l}\text { Zervixcarvinom, } \\
\text { Epidermodysplasia } \\
\text { verruciformis }\end{array}$ \\
\hline Adenoviren & $\begin{array}{l}\text { Keratokonjunktivitis } \\
\text { Fieber, } \\
\text { Halsschmerzen, Durchffall }\end{array}$ & $?$ & \\
\hline Herpes-simplex-Virus & $\begin{array}{l}\text { Entzündungen/Mund-, Genitalschleim- } \\
\text { haut }\end{array}$ & & $\begin{array}{l}\text { Herpes labialis } \\
\text { Herpes genitalis }\end{array}$ \\
\hline Varizella-Zoster-Virus & Windpocken & & Gürtelrose \\
\hline Zytomegalievirus & $\begin{array}{l}\text { Fieber, Lymphknotenschwellung (selten) } \\
\text { zytomegale Einschlusskörperchenkrank- } \\
\text { heit (in Feten und Neugeborenen) }\end{array}$ & & $\begin{array}{l}\text { bei Immundefekten: Pneumonie, } \\
\text { Hepatitis, Choriomeningitis }\end{array}$ \\
\hline Humane Herpesviren 6, 7 & Dreitagefieber & & $?$ \\
\hline
\end{tabular}

Chronisch-persistierende Virusinfektion. Die Wirtszelle überlebt die Virusinfektion, produziert aber kontinuierlich geringe Mengen von Viren und ist damit chronisch-persistierend infiziert. Bestimmte Viren haben sich an ihre Wirte sehr gut angepasst. Ihre Replikationsstrategien schädigen die Zelle daher nicht akut, lediglich langfristig kann es auch hier zum Tod der Zelle kommen. Diese Viren haben meist auch vielfache Mechanismen entwickelt, den immunologischen Abwehrmechanismen des Wirtes zu entgehen. Eine Möglichkeit dafür ist die kontinuierliche Variation der Domänen in den Oberflächenproteinen, an die sich neutralisierende Antikörper binden. Diesen Weg beschreiten beispielsweise die Humanen Immundefizienzviren und die Hepatitis-C-Viren.

Latent infizierte Zellen. Die Wirtszelle überlebt die Virusinfektion und das Virusgenom bleibt in latentem Zustand erhalten, ohne dass neue infektiöse Viren gebildet werden. Die Genome können jedoch durch bestimmte äußere Einflüsse auf die Zellen zur erneuten Expression der Virusgene und Synthese von infektiösen Viren angeregt werden. Diese sind dann wiederum in der Lage, neuerlich Zellen zu infizieren und zu schädigen, wodurch rekurrierende, wiederkehrende Erkrankungssymptome (Rezidive) auftreten.
Viren, die im Menschen chronisch-persistierende oder latente Infektionsformen verursachen, sind in • Tabelle 10.4 zusammengefasst. Neben der kontinuierlichen Schädigung der Zellen bestimmter Organe ihrer Wirte sind viele dieser Infektionserreger auch in der Lage, die von ihnen befallenen Zellen zu immortalisieren. Diese erhalten dadurch die Fähigkeit zur unendlichen Teilung, ein Vorgang, der mit der malignen Entartung zu einer Tumorzelle einhergehen kann.

\subsubsection{Tumorbildung durch Viren}

\section{(8)}

Man schätzt, dass etwa 15 bis 20 Prozent aller Tumorerkrankungen des Menschen kausal mit Virusinfektionen zusammenhängen.

In all diesen Fällen ist es nicht die akute Infektion, die zur Tumorbildung führt. Es handelt sich in aller Regel um langsame, sich schrittweise ausbildende Vorgänge, die sich in der Folge von persistierenden oder latenten Infektionen entwickeln können (• Tabelle 10.4).

Folgende maligne Tumorerkrankungen des Menschen stehen mit einer Virusinfektion in direkter Verbindung:

- Primäres Leberzellkarzinom: Hepatitis-B- und Hepatitis-C-Viren 
- Zervixkarzinom und Karzinome der Genitalschleimhaut, Epidermodysplasia verruciformis und verschiedene bösartige Hauttumoren: Papillomviren als wichtigste Tumorviren des Menschen

- Burkitt-Lymphom (B-Zell-Lymphome bei Kindern in Afrika), Nasopharynxkarzinom: Epstein-Barr-Virus

- Kaposi-Sarkome, Effusionslymphome, multizentrische Castleman-Erkrankung: Humanes Herpesvirus Typ 8

- Adulte T-Zell-Leukämie: humanes T-Zell-Leukämievirus I (HTLV-1)

Adenoviren, deren Infektion beim Menschen bisher nicht eindeutig mit Krebserkrankungen assoziiert werden konnten, rufen bei neugeborenen Nagetieren Tumoren hervor. Sie sind ein wichtiges Modellsystem zur Aufklärung der molekularen Prozesse bei der Transformation der Zellen.

Die meisten Viren, die mit Tumorerkrankungen des Menschen verbunden sind, haben ein DNA-Genom. Tumorerzeugende RNA-Viren sind nur die Hepatitis-C-Viren, die zur Familie der Flaviviren zählen und Leberkarzinome verursachen, sowie die zu den Retroviren gehörenden humanen T-Zell-Leukämieviren, die an der Ausbildung der sog. adulten T-Zell-Leukämie (ATL) beteiligt sind.

Tumor-erzeugende RNA-Viren (Oncornaviren) gehören zu den Retroviren und besitzen virale Onkogene.

Retroviren als Verursacher von Tumorerkrankungen bei Tieren waren schon früh bekannt: 1911 hatte Peyton Rous beschrieben, dass Viren bei Geflügel Sarkome hervorrufen. Später fand man, dass dieses Rous-Sarkom-Virus Zellen auch in der Gewebekultur transformieren kann ( $\mathrm{Abb}$. 10.12). Neben den Rous-Sarkom-Viren können eine Vielzahl von weiteren Retroviren aus den Gattungen der $\alpha$-, $\beta$ und $\gamma$-Retroviren ( $\bullet$ Tabelle 10.1) bei Vögeln und Nagetieren unterschiedliche Krebserkrankungen wie Lymphome, Karzinome und Sarkome auslösen. Die meisten wurden aus Inzuchtstämmen der jeweiligen Tierarten oder aus Zellkulturen isoliert, sie verursachen in der Natur die entsprechenden Tumoren nur selten. Eine Ausnahme sind die Leukoseviren der Katze (FeLV), welche die Katzenleukose unter natürlichen Bedingungen übertragen.

Das tumorerzeugende Potential dieser Viren beruht auf ihrer Fähigkeit zur Synthese von transformationsaktiven Proteinen, die von viralen Onkogenen (v-/onc/) codiert werden ( $\vee$ Kap. 35.3). Die v-Onc-Proteine sind mit den zellulären Proto-Onkogenen verwandt (c-Onc), die an der Regulation von Zellteilung und -wachstum beteiligt sind. Die v-Onc-Proteine sind aber gegenüber den jeweiligen Proto-Onkogenen durch Mutationen so verändert, dass sie im Gegensatz zu diesen konstitutiv, das heißt andauernd aktiv sind. Diese Daueraktivität leitet dann die unkontrollierte Teilung der Zellen ein. Über die Entstehung von viralen Onkogenen ( $\triangleright$ Kap. 35.3).
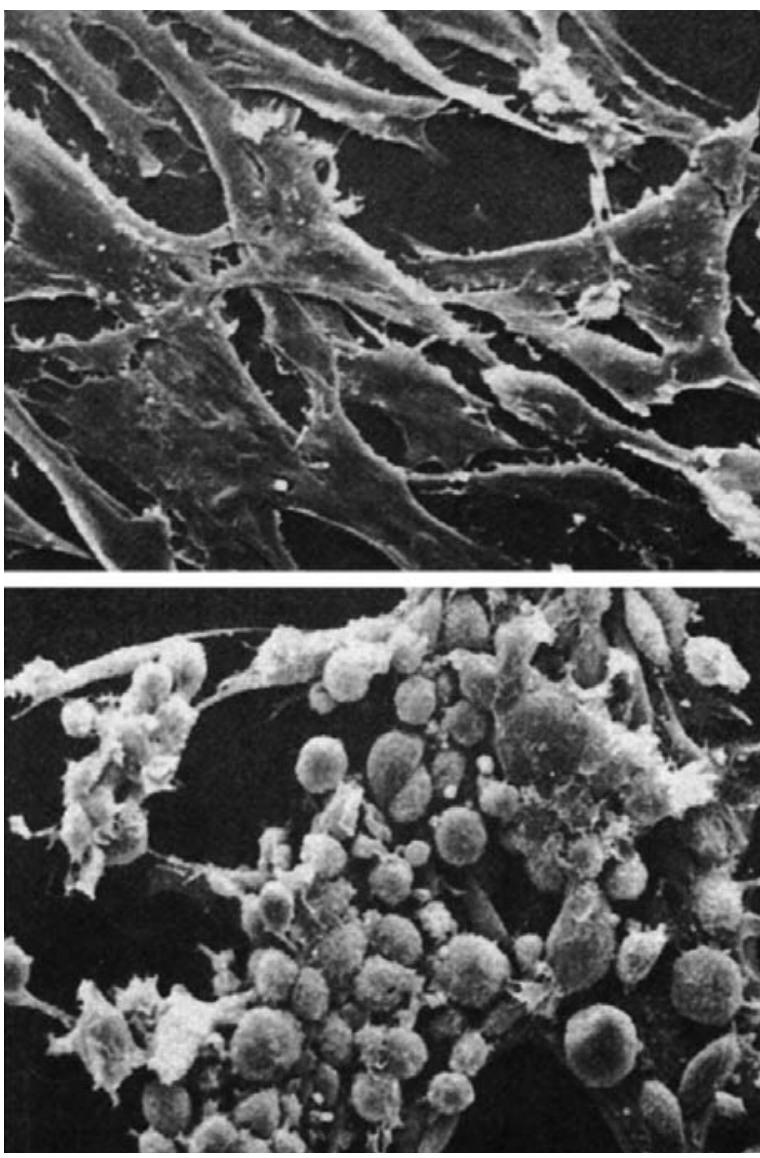

- Abb. 10.12. Transformation von Fibroblasten-Zellkulturen durch das Rous-Sarkom-Virus. Normale Fibroblasten sind flach, gestreckt und bilden einen dichten Zellrasen aus (oben). Nach der Infektion mit dem Virus runden sich die Zellen ab, lösen sich von der Unterlage und wachsen in größeren Haufen unkontrolliert (Aufnahme von G.S. Martin, Berkeley)

DNA-Viren verändern die Aktivität von Tumorsuppressoren.

Die DNA-Tumorviren und auch das Hepatitis-C-Virus besitzen keine v-/onc/-Gene. Die DNA-Tumorviren schalten vielmehr durch bestimmte virale Regulatorproteine gezielt die Funktion von zellulären Tumorsuppressorproteinen (Antionkogenen, \ Kap. 35.4) aus. Tumorsuppressorproteine oder Anti-Onkogene sind eine Gruppe von zellulären Regulatorproteinen. Zu ihnen zählt man neben anderen das Anti-Onkogen p53 und die sog. Retinoblastom-Proteine Rb105/107. Alle haben die Aufgabe, die Teilungsrate der Zellen zu kontrollieren ( $\triangleright$ Kap. 7.1.3, 35.4.2).

Viren sind i. Allg. darauf angewiesen, dass sich ihre Wirtszellen möglichst schnell teilen: Ihr eigener parasitärer Vermehrungszyklus benötigt die hohen Stoffwechselraten und den Energieumsatz von proliferierenden Zellen. Einige Viren haben deshalb Mechanismen entwickelt, die Zellen zur Teilung anzuregen. Ihnen ist gemeinsam, dass sie die zellulären Regulatoren der Zellteilung, nämlich die Tumorsuppressorproteine, in ihrer Aktivität beeinflussen: 
- Das E6-Protein der Papillomviren bindet sich an das p53-Protein ( Kap. 35.4.2) und bewirkt dessen Ubiquitinylierung. Dieses wird daraufhin durch die Proteasomen abgebaut, die Zellen verarmen an p53 und treten verfrüht in die Mitose ein

- Das E7-Protein der Papillomviren interagiert mit den Retinoblastom-Protein Rb105 ( Kap. 7.1.3, 35.4.2). Dieses liegt in seiner unphosphorylierten Form im Komplex mit den Transkriptionsfaktoren E2F und DP1 vor und inaktiviert diese. Die Bindung des E7-Proteins bewirkt, dass der Komplex mit den E2F- und DP1-Proteinen gelöst wird und diese ihre Aktivität entfalten können. Die Zellen treten damit verfrüht von der G1- in die S-Phase des Zellzyklus ein. Ähnlich wie das E7-Protein der Papillomviren wirkt auch das E1A-Protein der Adenoviren

- Das X-Protein der Hepatitis-B-Viren tritt in Wechselwirkung mit dem p53-Protein und dem DDB1-Protein (damaged DNA binding protein) der Zellen. Man vermutet, dass hierdurch die für die Aktivität des p53 notwendige Tetramerisierung unterbunden wird. Eine ähnliche Wirkung scheint auch das E1B-Protein der Adenoviren zu besitzen. Auch das DDB1-Protein wird aktiv, wenn in den Zellen DNA-Schädigungen vorliegen. Seine Aktivität verzögert den Übergang von der $\mathrm{G}_{1}$ - in die S-Phase des Zellzyklus

- Darüber hinaus findet man bei allen menschlichen Tumorviren, dass sie die Aktivität verschiedener Cycline sowie der Cyclin-abhängigen Kinasen beeinflussen. Als Folge treten die Zellen zu schnell in die S- beziehungsweise in die M-Phasen des Zellzyklus ein. Den Viren wird so ermöglicht, sich zu vervielfältigen und Nachkommen zu produzieren. Dadurch schädigen sie die Wirtszellen üblicherweise schwer

(

Die Immortalisierung der Zellen durch Viren ist von mehreren Einzelschritten abhängig.

\section{In Kürze}

Viren sind obligate Zellparasiten. Während der Infektion nehmen sie Einfluss auf die Stoffwechselprozesse und die Teilung der Zellen.

Manche Viren schädigen ihre Wirte so stark, dass die infizierten Zellen absterben. Häufig kommt es zur Apoptose, daneben tragen nekrotisierende und immunpathologische Prozesse zur Schädigung der infizierten Zellen und Gewebe bei.

Wenn die zellschädigenden Ereignisse nicht stark ausgeprägt sind, können sich persistierende oder latente Infektionsformen etablieren.

Die Einleitung der Zellteilung mit der Folge der gesteigerten Virusproduktion kann nicht allein die Immortalisierung der Zellen bewirken, hierzu bedarf es zusätzlicher Ereignisse. Alle Tumorviren des Menschen verursachen persistierende oder latente Infektionen - sie verbleiben also nach der Erstinfektion im Organismus und produzieren dabei kontinuierlich oder in Abständen Nachkommen. Während dieser lang andauernden Infektionen kann es $\mathrm{zu}$ »Unfällen« kommen, verbunden mit der Folge, dass der Infektionszyklus unterbrochen wird und die Bildung von neuen Viren unterbleibt, die erhöhte Teilungsrate aber aufrechterhalten wird. Hierfür können unterschiedliche Vorgänge verantwortlich sein:

- Das gesamte Virusgenom oder Teile davon wird in die Zell-DNA integriert. Durch die damit verbundene Zerstörung von Virusgenen oder durch die Deletion von Teilen des Virusgenoms ist der Infektionszyklus unterbrochen

- Die Viren verändern sich durch Mutationen, welche ihre Replikation unterbinden

- Die Viren gelangen in Zellen, in welchen der Infektionszyklus nicht vollständig ablaufen kann. Bei diesen abortiven Infektionen erfolgt nur die Synthese eines Teils der frühen Virusproteine - darunter die Regulatoren, welche die Aktivität der Anti-Onkogene beeinflussen

Die geschilderten Ereignisse reichen jedoch noch immer nicht aus, um eine sich schnell und dauerhaft teilende - das heißt immortalisierte - Zelle zur transformierten Tumorzelle werden zu lassen. Hierfür sind zusätzliche Vorgänge notwendig. Die Zellen müssen nämlich dem Immunsystem entgehen, welches normalerweise derartig veränderte Zellen als »fremd« erkennen kann. Auch muss das Programm der Apoptose ausgeschaltet werden. Es sind also in allen Fällen viele Schritte, die bei der virusbedingten Zelltransformation und Tumorbildung zusammenwirken müssen.

Persistierende Virusinfektionen können die Basis für die Immortalisierung der infizierten Zellen sein. Dabei beeinflussen die Viren über die Funktion ihrer Regulatorproteine zelluläre Tumorsuppressorproteine, mit der Folge einer erhöhten Zellteilungsrate. In Verbindung mit zusätzlichen Einflüssen können diese Zellen transformiert werden, maligne entarten und sich zu Tumoren ausbilden. 


\subsection{Diagnostik von Virusinfektionen}

D Bei der Diagnostik von Virusinfektionen weist man die Infektionserreger selbst oder die gegen sie gerichteten Immunreaktionen nach.

Die heute durchgeführte spezifische Diagnostik von Viruserkrankungen beruht auf molekularbiologischen Methoden. Man unterscheidet dabei zwei grundsätzlich unterschiedliche Vorgehensweisen:

- Den direkten Nachweis der Viren bei akuten oder chronisch-persistierenden Infektionen

- Den indirekten Nachweis der Virusinfektion über die sich im Infektionsverlauf ausbildende spezifische Immunantwort des infizierten Organismus

\subsubsection{Direkter Virusnachweis}

D Um Viren direkt nachzuweisen, muss man die Erreger oder ihre Erbinformation vervielfältigen.

Virusvermehrung. Eine Voraussetzung für den direkten Nachweis von Viren ist meist ihre Vermehrung. Nur gelegentlich, und dann überwiegend bei akuten Infektionen, finden sich die Viren in solch großen Konzentrationen im Organismus, dass man auf diesen Schritt verzichten kann. Die Virusvermehrung kann nur in Wirtszellen erfolgen. Deswegen ist ihr Vorhandensein in kultivierbarer Form eine Voraussetzung für den Virusnachweis. Dies ist nicht immer gewährleistet. So stehen keine Zelllinien oder andere Kultursysteme zur Verfügung, in welchen man beispielsweise die Hepatitis-B-Viren oder das Parvovirus B19 vermehren kann. Der erfolgreichen Anzucht schließen sich geeignete Systeme zum Nachweis der Viren in den Kulturen an. Dazu werden neben der klassischen Methode der Elektronenmikroskopie Hämagglutinations-, Immunfluoreszenz- und ELISA-Tests (enzyme linked immunosorbent assay) eingesetzt.

Nachweis viraler Nucleinsäuren. Die Polymerase-Kettenreaktion (PCR) ( Kap. 7.3) ist am besten zum schnellen, hochspezifischen Nachweis der viralen Nucleinsäuren geeignet, der im positiven Fall als direkter Beweis für das Vorhandensein der Erreger gewertet werden kann. Mit ihrer Hilfe kann man in den Patienten aber auch das Vorhandensein von latent in den Zellen vorliegenden Virusgenomen zeigen. Inzwischen stehen auch automatisierte PCR-Systeme zur quantitativen Bestimmung der Anzahl von viralen Genomäquivalenten im Probenmaterial zu Verfügung. Diese Testsysteme zeichnen sich durch eine Empfindlichkeit aus, die den Nachweis von theoretisch einem Virusgenom in der zu untersuchenden Probe ermöglicht.

\subsubsection{Bestimmung der Immunantwort gegen Virusproteine}

D Der Nachweis spezifischer Immunreaktionen ist ein indirekter Hinweis auf die Infektion mit den fraglichen Viren.

Viren sind oft nur für kurze Zeit im Patienten vorhanden. Deswegen muss die Diagnose häufig indirekt gestellt werden, das heißt durch die Bestimmung der Immunreaktion, die sich während der Infektion gegen die jeweiligen Erreger ausbildet. Hierzu zählen spezifische Immunglobuline (Antikörper), die sich gegen das Virus beziehungsweise gegen einzelne seiner Proteine oder Proteindomänen richten ( Kapitel 34.3.4). Antikörper der Subklasse IgM weisen i. Allg. darauf hin, dass es sich um eine akute oder erst kürzlich erfolgte Infektion handelt. Sind dagegen IgG-Antikörper gegen ein bestimmtes Virus nachweisbar, dann lassen sie auf eine länger zurückliegende, bereits abgelaufene Infektion schließen. Sie bleiben nach einer Infektion meist lebenslang im Blut und sind auch ein Anzeichen dafür, dass die jeweilige Person vor einer Neuinfektion mit dem gleichen Erregertyp geschützt ist, also Immunität vorliegt. Antikörper weist man heute üblicherweise in Western-Blot- oder ELISA-Tests nach.

Antikörpernachweis durch Western Blot. Ausgangsmaterial sind Präparationen von in Zellkultur gezüchteten Viren, in welchen die Strukturproteine der Erreger vorhanden sind. Eine Alternative sind durch gentechnische Verfahren gewonnene rekombinante Virusproteine, deren Handhabung im Vergleich zu gezüchteten Viren wesentlich ungefährlicher ist.

Die viralen Proteine werden nach ihrer Molekülmasse durch SDS-Polyacrylamidgel-Elektrophorese ( $\bullet$ Kap. 3.2.2) aufgetrennt und auf eine Nitrocellulosemembran übertragen. Diese inkubiert man mit den Patientenseren, die auf ihren Gehalt an virusspezifischen Antikörpern untersucht werden sollen. Falls die Seren solche Immunglobuline enthalten, lagern sich diese spezifisch an die Proteinbanden an. Die Komplexe können durch die nachfolgende Inkubation mit sekundären Antikörpern, die gegen den Fc-Teil menschlicher Immunglobuline gerichtet und einem MarkerEnzym - beispielsweise der Meerrettichperoxidase - gekoppelt sind, nachgewiesen werden. Nach Zugabe eines unlöslichen Substrats des Marker-Enzyms färben sich die Protein-Antikörper-Komplexe als dunkle Banden und werden somit sichtbar (• Abb. 10.13).

Antikörpernachweis in ELISA-Tests. Auch hier verwendet man Proteinpräparationen der entsprechenden Viren. Diese werden in sog. Mikrotiterplatten mit 96 Vertiefungen aus speziell behandeltem Polystyrol pipettiert, wo sie fest gebunden werden. Nach Zugabe Antikörper-enthaltender Seren bilden sich Protein-Antikörper-Komplexe aus, die - wie oben beschrieben - mit Peroxidase-gekoppelten se- 


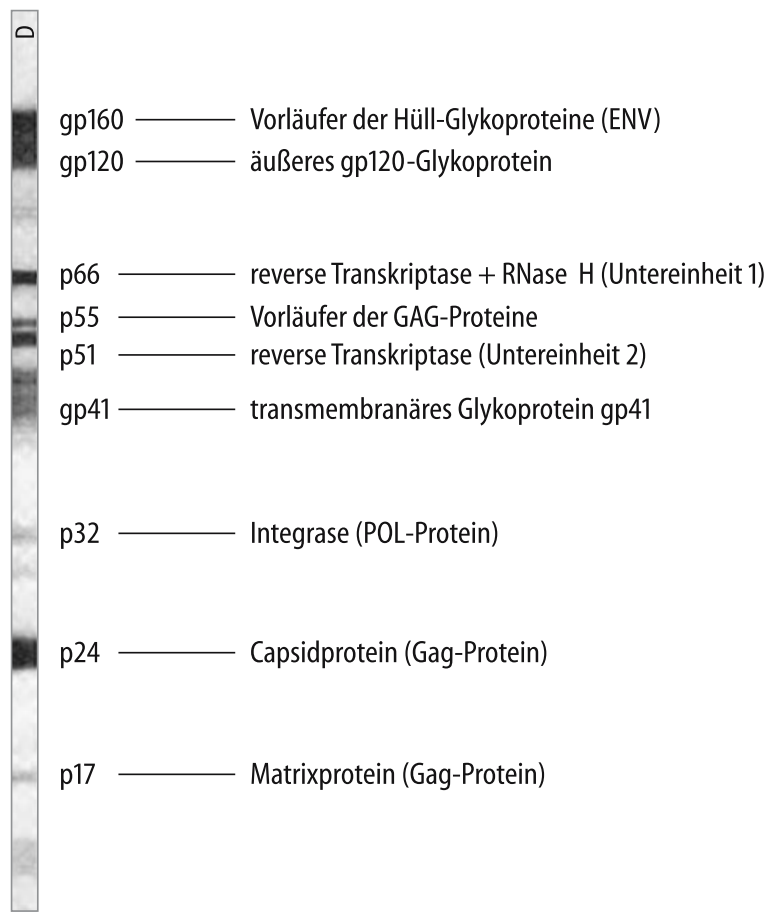

- Abb. 10.13. Beispiel für einen Western-Blot. Gezeigt ist der Nachweis von HIV-spezifischen Antikörpern aus dem Serum einer infizierten Person. Das Molekulargewicht der von den im Serum vorhandenen Antikörpern erkannten Proteinbanden ist in kDa angegeben. Es handelt sich um Strukturproteine und Enzyme von HIV

kundären Antikörpern nachweisbar sind. Im Unterschied zum Western-Blot setzt man beim ELISA-Test ein lösliches Substrat (o-Phenylendiamin) ein, weil dies eine quantitative Auswertung und eine gleichzeitige Aussage über die Menge der Antikörper im Serum ermöglicht (• Abb. 10.14).

(8)

Ob Immunglobuline die Fähigkeit zur Neutralisierung des Virus besitzen, muss gesondert nachgewiesen werden.

Mit den Immunglobulinen können aber auch bestimmte Funktionen, beispielsweise ihre Fähigkeit, das entsprechende

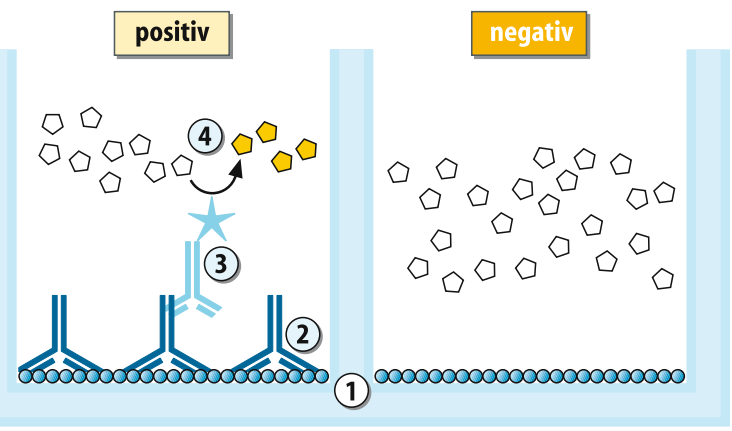

- Abb. 10.14. ELISA-Test zum Nachweis von Antikörpern gegen virale Proteine. 1 An den Boden der Näpfe gebundenes Virusprotein; 2 Patientenserum enthält im positiven Fall Antikörper gegen das Virusprotein; 3 sekundärer Antikörper gegen den Fc-Teil der Patientenimmunoglobuline, mit Meerrettich-Peroxidase $(\star)$ gekoppelt; 4 Zugabe von Substrat (o-Phenylendiamin); wird von der MeerrettichPeroxidase umgesetzt, im positiven Fall Gelbfärbung

Virus zu neutralisieren, verbunden sein. Um dies nachzuweisen, mischt man definierte Mengen infektiöser Viren mit den Antikörpern aus den Patientenseren und versetzt mit dieser Suspension Zellen in der Gewebekultur. Die Antikörper sind neutralisierend, wenn die in vitro-Infektion gehemmt ist und die Bildung von Nachkommenviren unterbleibt.

(D) Der Infektionsverlauf lässt sich durch direkte und indi-
rekte Nachweisverfahren kontrollieren.

Durch die Kombination des direkten Virusnachweises beim Patienten mit der Charakterisierung der im Infektionsverlauf entstehenden Immunantwort kann man Virusinfektionen diagnostizieren und ihren Verlauf kontrollieren (- Abb. 10.15). Es existieren allerdings Perioden, in welchen man weder Virus noch Antikörper findet, die zu untersuchende Person aber trotzdem infiziert ist:

Zustand direkt nach dem Erregerkontakt. Theoretisch genügt ein infektiöses Viruspartikel, um eine Infektion auszulösen. Bevor sich die Viren allerdings vermehrt haben und in nachweisbaren Mengen im Körper vorhanden sind, können je nach Virustyp einige Tage oder auch Wochen
- Abb. 10.15. Serologischer Verlauf einer Virusinfektion am Beispiel des Ringelrötelnvirus (Parvovirus B19). Der Phase der Virämie (Virus im Blut) und der Symptome (Fieber, Hautausschlag) folgen die Synthese von IgMAntikörpern gegen die Strukturproteine VP. Die IgM-Antikörper werden von IgG-Antikörpern gegen die Strukturproteine abgelöst, welche lebenslang erhalten bleiben

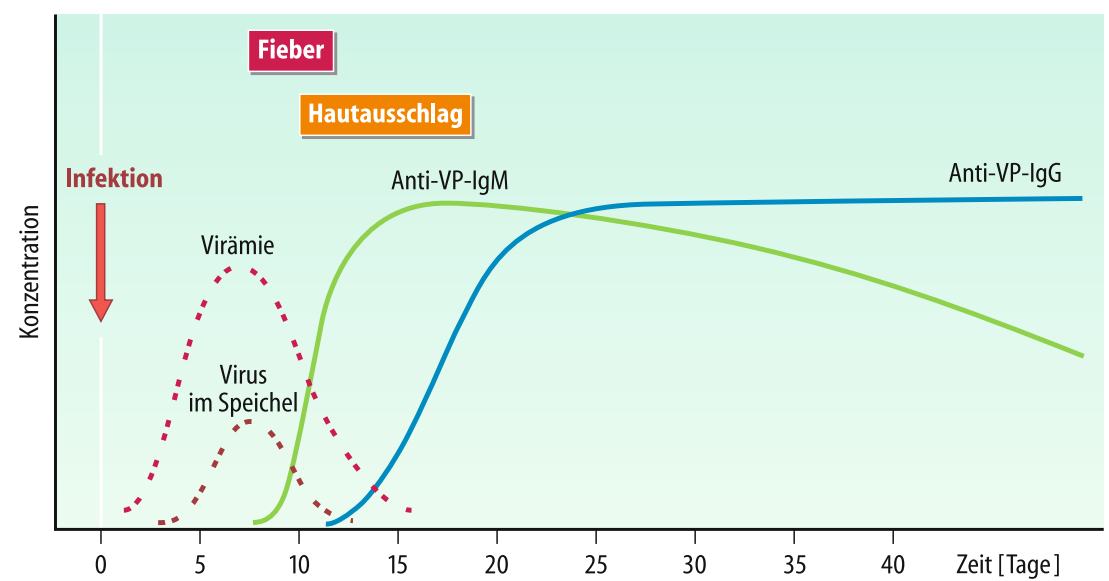


vergehen. In dieser Inkubationsphase werden meist keine Anzeichen einer Erkrankung beobachtet. Der Patient ist jedoch bereits infiziert, die Viren sind aber noch nicht nachweisbar.

Zustand nach der ersten Vermehrungsphase (Virämie). Eine weitere Phase, in der man trotz Infektion weder Virus noch Antikörper findet, kann sich an die erste Vermehrungsphase der Erreger im Patienten anschließen. Dieser Zeitraum macht insbesondere bei Infektionen mit den Humanen Immundefizienzviren diagnostische Probleme: Nach anfänglicher Vermehrung gehen die Viren im Patienten in ein Stadium der Latenz über. Infektiöse, freie Viruspartikel sind im Blut nicht mehr vorhanden, ihre Erbinformation liegt nun als DNA integriert im Genom einiger Blutzellen

\section{In Kürze}

Virusinfektionen können durch den direkten Nachweis der Erreger diagnostiziert werden:

- Durch die Vermehrung (Züchtung) der Erreger in der Zellkultur. Anschließend werden sie mit immunchemischen oder elektronenmikroskopischen Testverfahren nachgewiesen

- Durch Vermehrung (Amplifizierung) der Erbinformation der Viren über die Polymerase-Kettenreaktion (PCR). Moderne quantifizierbare PCR-Tests gestatten die Bestimmung der im Blut oder anderen Untersuchungsmaterialien vorhandenen Zahl der Virusgenome vor - deren Zahl ist jedoch zu gering, um sie in einer Blutprobe von üblicherweise 5 bis $10 \mathrm{ml}$ nachzuweisen. $\mathrm{Zu}$ diesem Zeitpunkt beginnt sich die Immunantwort auszubilden, Antikörper sind jedoch auch noch nicht in nachweisbaren Konzentrationen vorhanden. Folglich erhält man auch in dieser Phase kein positives diagnostisches Ergebnis. In den ersten Jahren nach der Entdeckung des humanen Immundefizienzvirus hat dieses Problem dazu geführt, dass einige Blutspenden virusinfizierte Zellen enthielten, obwohl die Spender symptomfrei und diagnostisch unauffällig waren. Deswegen ist man dazu übergegangen, alle Blutkonserven in Quarantäne zu nehmen und vor ihrer Verwendung einige Wochen zu lagern. Ergibt eine zweite Testung des Blutspenders wiederum ein negatives Ergebnis, wird die Konserve zur Verwendung freigegeben.

Ein indirektes Verfahren zum Virusnachweis ist die Bestimmung der lgM- und lgG-Antikörper gegen die Virusproteine (Antigene). Dieses Verfahren gestattet Rückschlüsse auf akute oder zurückliegende Infektionen mit bestimmten Viren.

Durch die Kombination des direkten Erregernachweises mit den indirekten Methoden zur Analyse der spezifischen Immunreaktionen lässt sich der Verlauf einer Virusinfektion kontrollieren.

\subsection{Prophylaxe und Therapie von Virusinfektionen}

\subsubsection{Impfung}

Unter dem Begriff der Impfung versteht man die Erzeugung einer Immunität gegen Infektionen durch Immunisierung. Grundsätzlich kann man zwei Typen der Immunisierung unterscheiden:

1. Die passive Immunisierung beruht auf der Gabe von Immunglobulinen, die ein bestimmtes Virus neutralisieren können. Sie wird nur in besonderen Fällen angewandt, beispielsweise dann, wenn die zu schützende Person erst vor kurzem Kontakt mit einem Virus hatte oder wenn das Risiko der Exposition mit Erregern in den folgenden Wochen nicht auszuschließen und eine aktive Impfung nicht möglich ist, wie bei kurzfristig geplanten Reisen in Länder der Dritten Welt (Expositionsprophylaxe). Der Schutz durch die Antikörperpräparate hält nur wenige Wochen an, da die Immunglobuline im Körper schnell abgebaut werden

2. Die aktive Immunisierung erzeugt einen lang anhaltenden Schutz vor der Infektion. Bei der aktiven Im-

munisierung wird im Organismus eine Virusinfektion simuliert und es bildet sich eine schützende Immunantwort aus. Im Idealfall ähnelt die durch die Impfung erzeugte Immunreaktion derjenigen, die sich auch bei der Infektion ausbilden würde, und besteht aus einer Kombination von neutralisierenden Antikörpern und zytotoxischen T-Zellen ( $>$ Kap. 34.3.3). Die aktive Impfung kann mit Lebend- und mit Totimpfstoffen erfolgen

D Impfungen mit Lebend- oder Totimpfstoffen induzieren im Organismus eine schützende Immunantwort.

Impfstoffe dienen zur Prävention, das heißt, sie sollen bei den Impflingen einen Schutz aufbauen, der sie bei Kontakt mit dem jeweiligen Erreger vor der Infektion und somit vor der Erkrankung schützt. • Tabelle 10.5 gibt einen Überblick zu den derzeit in Deutschland zugelassenen Impfstoffen zum Schutz vor Virusinfektionen.

( Durch Mutation abgeschwächte Virusvarianten lassen sich als Lebendimpfstoff verwenden.

Attenuierte (abgeschwächte), replikationsfähige Erreger. Lebendimpfstoffe enthalten attenuierte, replikationsfähige 


\begin{tabular}{l|l|l|l|}
$\begin{array}{l}\text { - Tabelle 10.5. In Deutschland zugelassene Impfstoffe zur Ver- } \\
\text { hinderung von Virusinfektionen beim Menschen }\end{array}$ \\
$\begin{array}{l}\text { Lebendimpfstoffe/ } \\
\text { attenuierte Viren }\end{array}$ & $\begin{array}{l}\text { Totimpfstoffe } \\
\text { abgetötete Viren }\end{array}$ & $\begin{array}{l}\text { Proteinkom- } \\
\text { ponenten }\end{array}$ \\
\hline $\begin{array}{l}\text { Poliovirus } \\
\text { Gelbfiebervirus }\end{array}$ & Poliovirus & Hepatitis-B-Virus \\
\hline Masernvirus & Hepatitis-A-Virus & \\
\hline Mumpsvirus & FSME-Virus & \\
\hline Rötelnvirus & Tollwutvirus & \\
\hline $\begin{array}{l}\text { Varicella-Zoster- } \\
\text { Virus }\end{array}$ & & \\
\hline
\end{tabular}

Erreger, die sich im Impfling vermehren. Attenuierte Viren ähneln den krankheitserzeugenden Erregern hinsichtlich ihres Aufbaus, der Proteinzusammensetzung und des Infektionsverhaltens. Sie können bestimmte Zellen infizieren und die Synthese von viralen Proteinen und Partikeln einleiten. Im Vergleich zum virulenten Wildtypvirus, von dem sie sich durch verschiedene Mutationen unterscheiden, verursachen sie begrenzte oder abgeschwächte Infektionen. Der Organismus reagiert mit einer spezifischen Immunantwort und bildet dabei sowohl neutralisierende Antikörper als auch zytotoxische T-Zellen. Impfungen mit attenuierten Viren verleihen einen sehr guten, lang anhaltenden Impfschutz, Wiederholungsimpfungen zur Aufrechterhaltung des Impfschutzes sind nur in relativ langen Abständen von bis zu zehn Jahren erforderlich.

Rekombinante Viren. Eine neue Form der Lebendimpfstoffe stellen rekombinante Viren dar. Hierbei handelt es sich um gut erforschte, und in der Vergangenheit bereits erfolgreich eingesetzte Impfviren, meist um Vacciniaviren. Diese wurden in den vergangenen Jahrhunderten zur weltweiten Ausrottung der durch die Variola-Viren verursachten Pocken verwendet. Diese sehr komplexen Vacciniaviren werden durch gentechnologische Methoden so verändert, dass sie außer für ihre eigenen zur Infektion notwendigen Genprodukte auch für solche anderer Virustypen codieren. Diese für das Vacciniavirus unspezifischen Fremdgene werden im Infektionsverlauf im Impfling zusammen mit den viralen Genen exprimiert. Dies induziert eine Immunantwort sowohl gegen die Vacciniavirus-Proteine wie auch gegen die fremden Genprodukte. Derartige rekombinante Impfstoffe werden in einigen Ländern zur Bekämpfung der Wildtollwut in der Fuchspopulation eingesetzt. Für die Anwendung beim Menschen wurden sie bisher noch nicht zugelassen.

DNA-Impfstoffe. Ähnlich wirken die DNA-Impfstoffe, die sich ebenfalls in der Erprobung befinden. Sie beruhen auf Expressionsvektoren in der Form von zirkulären DNAPlasmiden, in welche man unter Kontrolle eines eukaryotischen Promotors mittels gentechnologischer Methoden das gewünschte Fremdgen einkloniert. Werden diese Vektoren als gereinigte DNA in den Muskel injiziert, dann erfolgt die Aufnahme der Nucleinsäuren durch die Muskelzellen, in welchen sie lange erhalten bleiben. Die Fremdgene werden transkribiert und die mRNAs in Protein übersetzt. Der Organismus leitet dann eine spezifische Immunantwort gegen die Fremdproteine ein. Derartige DNA-Impfstoffe wurden bisher in Tierexperimenten, v.a. in Nagetieren, erprobt und erwiesen sich hierbei als sehr erfolgreich. Ähnlich Erfolg versprechende Ergebnisse konnten allerdings in Primaten bisher nicht erzielt werden. Für den potentiellen Einsatz im Menschen ist daher noch erhebliche Entwicklungsarbeit notwendig.

Totimpfstoffe enthalten Viren, die sich nicht mehr vermehren können.

Totimpfstoffe können sich definitionsgemäß im Impfling nicht vermehren. Sie induzieren überwiegend die Bildung von spezifischen Antikörpern und müssen zur Steigerung der Immunantwort zusammen mit einen Adjuvans (Aluminiumhydroxid) appliziert werden, das die Einwanderung immunologisch aktiver Zellen an die Inokulationsstelle fördert. Bei der Verwendung von Totimpfstoffen sind zur Erhaltung des Immunschutzes Wiederholungsimpfungen in relativ kurzen Abständen nötig.

Die einfachste Form eines Totimpfstoffes stellt eine Präparation von Wildtypviren dar, die durch Behandlung mit Chemikalien (alkoholischen und aldehydischen Agenzien, $\beta$-Propiolacton) getötet wurden. Da auch die Virusgenome in vielen Fällen infektiös sind und die Bildung von Nachkommenviren einleiten können, müssen zur Zerstörung der Infektiosität Methoden eingesetzt werden, die auch die Virusgenome inaktivieren. Die Proteinkomponenten dürfen dabei jedoch nicht so weit denaturiert werden, dass sie ihre native Konfiguration verlieren und den viralen Strukturen nicht mehr ähneln.

Ist bekannt, welche der viralen Oberflächenkomponenten für die Induktion einer schützenden Immunantwort verantwortlich sind, dann kann das für dieses Protein codierende Gen über gentechnische Methoden in einem geeigneten Expressionssystem produziert, gereinigt und anschließend zusammen mit einem Adjuvans appliziert werden. Ein Beispiel hierfür ist der rekombinante Totimpfstoff, der zum Schutz vor Infektionen mit dem Hepatitis-BVirus zugelassen ist. Er enthält das Oberflächenprotein HBsAg dieses Virus, das in Saccharomyces cerevisiae produziert wird und sich zu vesikulären Partikeln zusammenschließt. Da derartige Impfstoffe frei von Virusgenomen und potentiell humanpathogenen Erregern sind, gelten sie als sehr sicher. 


\subsubsection{Chemotherapie}

(D Angriffspunkte für antivirale Therapeutika sind Virusenzyme, die in der Zelle nicht vorkommen.

Viren können sich als obligate Zellparasiten nur in lebenden Zellen vermehren und nutzen viele funktionelle Aktivitäten ihrer Wirte. Antiviral wirkende Substanzen müssen daher streng selektiv auf bestimmte Virusfunktionen zielen und sollten zelluläre Prozesse möglichst nicht beeinflussen. Die überwiegende Mehrzahl der heute verfügbaren Chemotherapeutika hemmt die Genomreplikation der Viren. Viele Viren verwenden hierfür eigene Polymerasen, die sich von zellulären Enzymen unterscheiden. Dies ermöglicht eine gezielte Hemmung dieser Virusaktivitäten. Daneben bieten aber auch andere Virusenzyme Angriffspunkte für antivirale Chemotherapeutika. Hierzu zählen u.a. die Protease, welche die Vorläuferproteine der Humanen Immundefizienzviren spaltet, die Protonenpumpe M2, die für die Freisetzung der Nucleocapside der Influenzaviren notwendig ist, sowie die Neuraminidase dieser Viren.

D Antiviral wirkende Therapeutika beeinflussen oft die Funktion der viralen Polymerasen.

Substanzen, welche die Genomreplikation der Viren hemmen, können in zwei Gruppen eingeteilt werden:

1. Nucleosidanaloga konkurrieren mit den natürlichen Basenderivaten und binden sich an die aktiven Zentren der Polymerasen. Sie hemmen die Funktion der Enzyme oder werden während der Replikation in die neu gebildeten Nucleinsäurestränge eingebaut und bewirken Kettenabbrüche

2. Nichtnucleosidische Hemmstoffe binden an Proteindomänen in der Nachbarschaft der aktiven Zentren der Enzyme

Viele der verfügbaren Nucleosidanaloga werden zur Behandlung von Herpesvirusinfektionen eingesetzt. Herpesviren haben einen sehr komplexen Aufbau und verfügen über die genetische Information für eine ganze Reihe von Enzymen, die am Nucleotid-Stoffwechsel und an der Genomreplikation beteiligt sind. Hierzu zählen unter anderen<smiles>Nc1nc2c(ncn2COCCO)c(=O)[nH]1</smiles>

Aciclovir<smiles></smiles><smiles>C1CCCC1</smiles><smiles>CC1OC2CC1O2</smiles>

2'-Desoxyguanosin

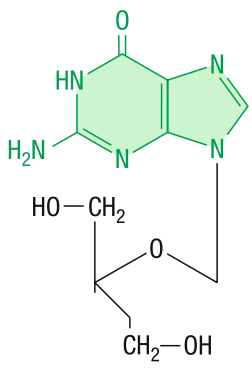

Ganciclovir
- Abb. 10.16. Strukturformeln von Aciclovir und Gangciclovir im Vergleich zum 2'-Desoxyguanosin eine Thymidinkinase, eine Ribonucleotid-Reduktase und eine DNA-Polymerase. Acycloguanosin (9-(2-Hydroxyethoxy)-methylguanin), ein Guanosinderivat mit einem azyklischen Zuckerrest (• Abb. 10.16), auch unter der Bezeichnung Aciclovir oder dem Handelsnamen Zovirax bekannt, wurde bereits 1977 entwickelt. Es wird seitdem zur Therapie von Infektionen mit Herpes-simplex- und Varicella-Zoster-Viren eingesetzt. Es beeinflusst die Thymidin-

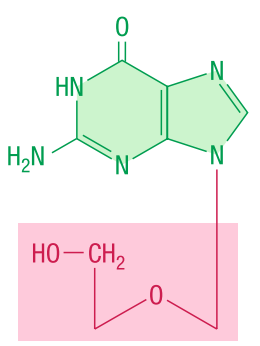

Acycloguanosin mit unvollständiger Desoxyribose

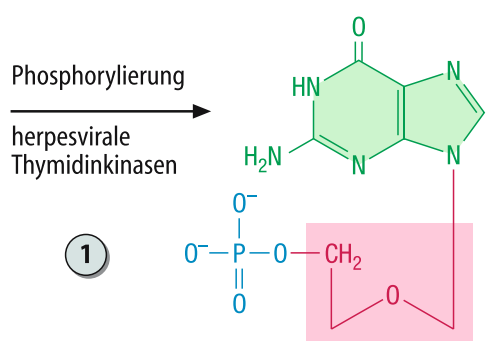

Acycloguanosin-Monophosphat Phosphorylierung $\mid$ zelluläre Kinasen<smiles>[C+]1CCCC1</smiles><smiles>Nc1nc2c(ncn2COCCOP(=O)([O-])OP(=O)([O-])OP(=O)([O-])[O-])c(=O)[nH]1</smiles>

Acycloguanosintriphosphat

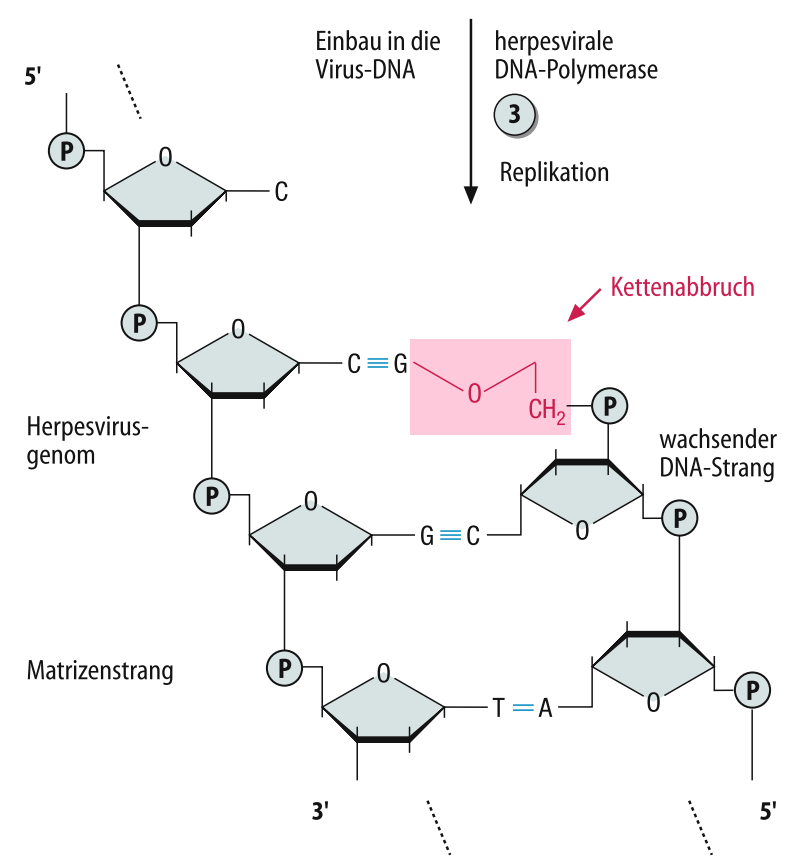

- Abb. 10.17. Mechanismus der Hemmwirkung von Aciclovir. (Einzelheiten $>$ Text) 
kinase und die DNA-Polymerase beider Virustypen. In einem ersten Schritt wird Acycloguanosin von der viralen Thymidinkinase als bevorzugtes Substrat akzeptiert und monophosphoryliert (• Abb. 10.17). Zelluläre Kinasen überführen es in das Triphosphat. Als solches wird es, ebenfalls selektiv, von den DNA-Polymerasen des Herpes-Virus verwendet und in neusynthetisierte Virusgenome, jedoch nicht in zelluläre DNA, eingebaut und bewirkt den Abbruch der Polymerisation. Wegen des spezifischen Aktivierungsmechanismus ist Aciclovir ausschließlich in Zellen wirksam, die mit Herpes-simplex- oder Varicella-Zoster-Viren infiziert sind. Durch Veränderung oder Anfügen zusätzlicher funktioneller Gruppen ist Aciclovir vielfach modifiziert worden. So erhielt man weitere antiviral wirkende Substanzen, zu denen unter anderem Ganciclovir zählt (- Abb. 10.16). Dieses setzt man bei Infektionen mit Cytomegalieviren ein. Es wirkt vermutlich über den gleichen molekularen Mechanismus wie Aciclovir, wird jedoch anscheinend von einer viralen Proteinkinase phosphoryliert, da Cytomegalieviren im Unterschied zu den anderen Herpesviren über keine Thymidinkinase-Aktivität verfügen.

D Zur Therapie von HIV-Infektionen setzt man Kombinationen von antiviralen Wirkstoffen ein.

Eine andere Gruppe von Nucleosidanaloga wird zur Therapie von Erkrankungen eingesetzt, die durch Infektionen mit den Humanen Immundefizienzviren verursacht sind. Als Erstes wurde 1987 die antiretrovirale Wirkung von Azidothymidin (3-Azido-3'-deoxythymidin, AZT, Handelsname: Zidovudine) beschrieben (• Abb. 10.18). Es handelt sich um ein Analogon des Thymidins, das an der 3'-Position der Ribose eine Azidogruppe besitzt. Zelluläre Kinasen überführen Azidothymidin in das Triphosphat, das bevorzugt von den reversen Transkriptasen der Retroviren als Substrat verwendet wird (• Abb. 10.19). Beim Umschreiben des einzelsträngigen RNA-Genoms in doppelsträngige DNA bewirkt es einen Kettenabbruch, da Azidothymidin keine 3'-OH-Gruppe zur Bildung der Phosphodiesterbindung besitzt. Hierdurch wird der Replikationszyklus der

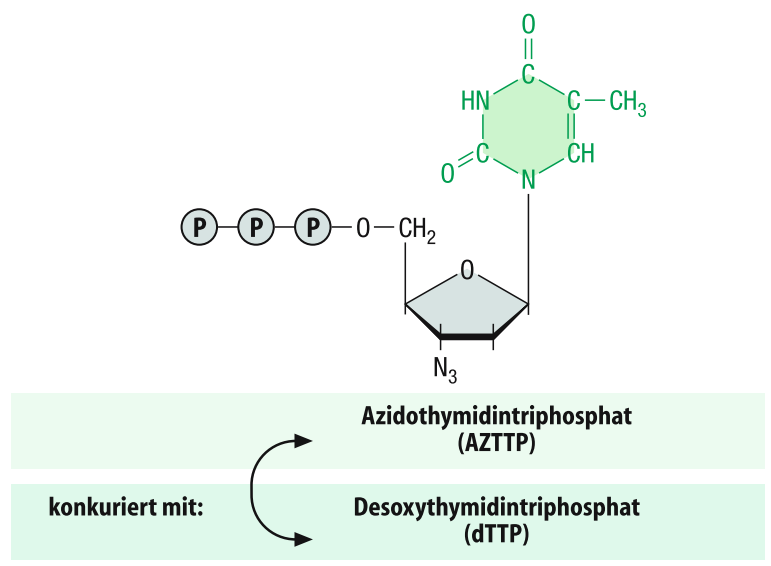

- Abb. 10.18. Strukturformel von Azidothymidin
Retroviren schon zu einem sehr frühen Stadium, nämlich noch vor Integration des Virusgenoms in die WirtszellDNA unterbunden. Die Affinität des Azidothymidin-Triphosphats zur reversen Transkriptase der Humanen Immundefizienzviren ist einhundert Mal höher als zu den zellulären DNA-Polymerasen $\alpha$ und $\beta$. In der Folge wurden weitere Nucleosidanaloga entwickelt, die man zur Therapie der HIV-Infektionen einsetzt. Hierzu zählen unter anderen das Cytosin-Analogon Didesoxycytosin (Zalcitabin, ddC)

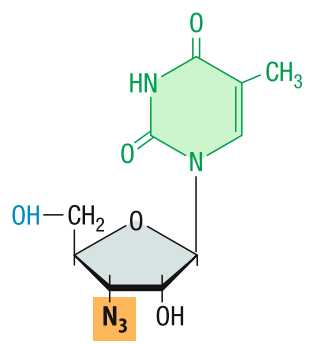

Azidothymidin

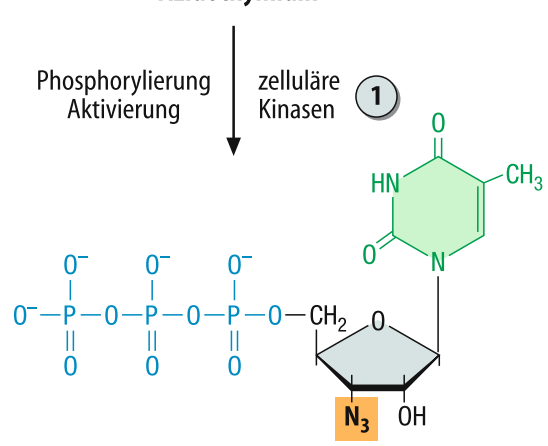

Azidothymidintriphosphat

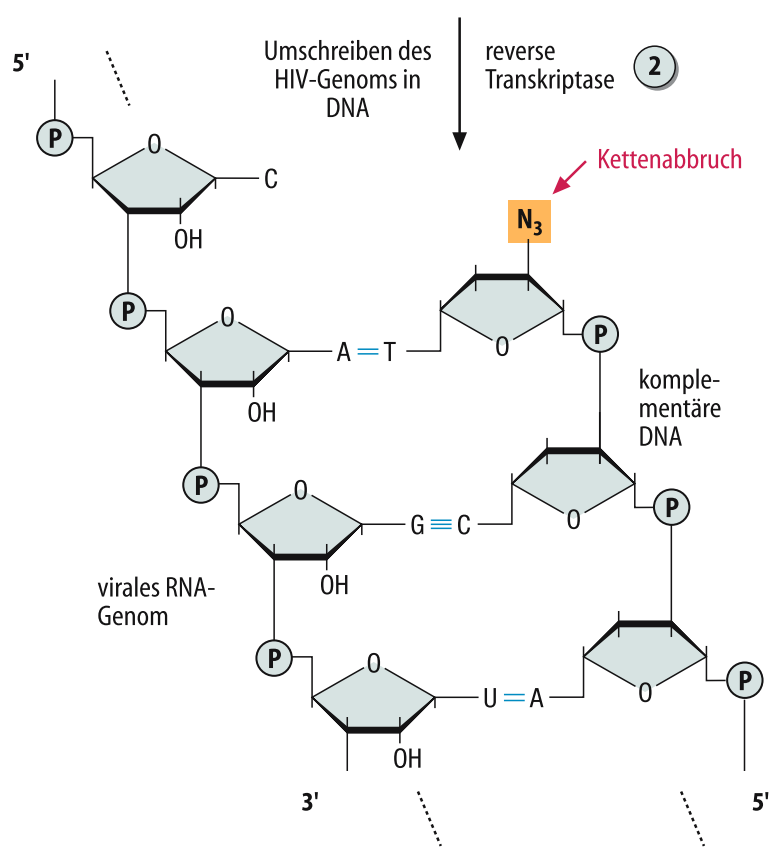

- Abb. 10.19. Mechanismus der Hemmwirkung von Azidothymidin 
und Didesoxyinosin (Didanosin, ddI), das als Analogon des Adenosin wirkt. Beiden Substanzen fehlt die $3^{\prime}-\mathrm{OH}-$ Gruppe an der Ribose, dadurch bewirken sie bei Einbau in die wachsenden Nucleinsäurestränge den Abbruch der Polymerisation.

Foscarnet, das Trinatriumsalz der Phosphonoameisensäure, hemmt als nichtnucleosidischer Hemmstoff die Genomreplikation verschiedener Viren. Es wirkt als Analogon von Pyrophosphaten. Die Pyrophosphat-Bindungsstelle liegt in Nähe des aktiven Zentrums der DNAPolymerase von Cytomegalieviren. Hieran bindet sich Foscarnet und hemmt die Aktivität des Enzyms, wobei es nichtkompetitiv zu den natürlichen Basen wirkt. Außerdem hemmt es die reverse Transkriptase der Retroviren, auch die der Humanen Immundefizienzviren. Eine ähnliche Wirkungsweise zeigt Nevirapin (Dipyridodiazepinon): diese antivirale Substanz bindet an die größere Untereinheit der reversen Transkriptase und hemmt so deren Aktivität.

( Neben den viralen Nucleinsäure-Polymerasen kann man auch andere Enzymfunktionen hemmen.

Amantadin (1-Aminoadamantan- $\mathrm{HCl}$ ) und Rimantadin ( $\alpha$-Methyl-1-adamantanmethylamin) sind polyzyklische, aliphatische Ringsysteme. Beide sind Hemmstoffe der Influenza-A-Virus-Infektion, sie inhibieren die Funktion des viralen M2-Proteins. Dieses ist in die Virusmembran eingelagert. Es bewirkt nach Aufnahme der Viren durch rezeptorvermittelte Endozytose die Ansäuerung des Vesikelinneren und ermöglicht die Freisetzung der Nucleocapside. Ist dieser Vorgang gehemmt, kann die Transkription und Replikation der viralen RNA-Segmente nicht stattfinden. Ebenfalls zur Therapie von Influenzavirus-A-Infektionen werden Inhibitoren der viralen Neuraminidase verwendet. Zanamivir (2,3-Didehydro-2,4-Dideoxy-4-Guanidino-NAcetyl-Neuraminsäure) und Oseltamivir (4-Acetamino-5Amino-3-(1-Ethylpropoxy)-1-Cyclohexen-1-Carbonylsäure) hemmen die rezeptorzerstörende Aktivität der Viren und bewirken, dass die neu gebildeten Nachkommenviren nicht effizient von der Zelloberfläche abgegeben werden. Folglich ist auch ihre Ausbreitung im Körper unterbunden und die Infektion kann immunologisch schneller kontrolliert werden.

Ribavirin (1-D-Ribofuranosyl-1,2,4-triazol-3-caroxamid, \ Kap. 19.1.5) hat eine breite antivirale Wirkung, jedoch auch eine nicht zu vernachlässigende Wirkung auf zelluläre Prozesse, worauf die mit seinem Einsatz verbundenen Nebenwirkungen zurückzuführen sind. Es ist mit dem Guanosin verwandt und wird durch zelluläre Kinasen zum Mono-, Di- und Triphosphat modifiziert. Als Monophosphat hemmt es die Inosinmonophosphat-Dehydrogenase und verursacht dadurch die Abnahme der intrazellulären GTP-Konzentration. Das Triphosphat inhibiert die Guanyltransferase, welche die 5'-Cap-Gruppe an die Enden der mRNAs anfügt. Dadurch wird letztendlich die Translation der viralen, aber auch der zellulären Transkripte verhindert. Auch werden durch die Ribavirin-Wirkung vermehrt Mutationen in den Genomen induziert. Trotz der Nebenwirkungen setzt man Ribavirin zur Therapie des Lassa-Fiebers und bei Lungenentzündungen von Kleinkindern ein, die mit dem respiratorischen Syncytialvirus infiziert sind.

Saquinavir und Invirase sind Hemmstoffe der Protease der Humanen Immundefizienzviren. Dieses Enzym spaltet während des Reifungsprozesses (• Abb. 10.4, 10.8) die Polyproteine Gag und Gagpol in die einzelnen Strukturkomponenten - ein Vorgang, der für die Ausbildung der Infektiosität der Viren unerlässlich ist. Die Hemmstoffe sind überwiegend von Peptiden abgeleitet, welche die Proteasespaltstellen in den Vorläuferproteinen simulieren.

(8)

Der Einsatz viraler Chemotherapeutika selektiert Virusvarianten, die durch Mutationen resistent sind.

Wegen der hohen Fehlerrate der viralen Replikationssysteme kommt es bei Einsatz von antiviralen Chemotherapeutika schnell zur Bildung von Virusvarianten, die durch die jeweiligen Substanzen nicht mehr hemmbar sind und deswegen bei ihrem Einsatz selektiert werden. Ein besonderes Problem ist die Therapie von Infektionen mit Humanen Immundefizienzviren. Schon kurze Zeit nach Einsatz von Hemmstoffen der reversen Transkriptase kommt es zu resistenten HI-Viren. Diese zeichnen sich durch Veränderungen der Aminosäuresequenz der reversen Transkriptase an den Bindungsstellen des Hemmstoffs aus. Da diese sich bei verschiedenen Hemmstoffen unterscheiden, setzt man heute Kombinationen der Nucleosidanaloga zur Therapie der HIV-Infektion ein und ergänzt das Spektrum durch nichtnucleosidische Inhibitoren und Hemmstoffe der Protease. Auf diese Weise soll es dem Virus unmöglich gemacht werden, alle für eine Resistenzentwicklung notwendigen Proteinregionen zu verändern, ohne dass dadurch auch die Überlebensfähigkeit der Viren beeinträchtigt wird. 


\section{In Kürze}

Präventive Maßnahmen gegen Virusinfektionen sind:

- Die passive Immunisierung, das heißt die Verabreichung von Immunglobulinen. Dies ist eine Möglichkeit, nach bereits erfolgter Exposition mit bestimmten Viren die Infektion frühzeitig einzugrenzen und die Erkrankung zu verhindern

- Die aktive Immunisierung. Hierbei täuscht man dem Organismus die Infektion mit einem bestimmten Virus vor, indem man abgetötete (inaktivierte) oder vermehrungsfähige, jedoch abgeschwächt wirkende (attenuierte) Viren in den Körper inokuliert. Das Immunsystem reagiert darauf mit der Ausbildung von Abwehrstoffen (Antikörpern und zytotoxischen T-Zellen). Diese schützen den Organismus bei einem späteren Kontakt mit den pathogenen Viren vor der Infektion und vor der Erkrankung
Durch Chemotherapie soll die Virusvermehrung im Körper unterbunden und der Erkrankungsverlauf positiv beeinflusst werden. Als Chemotherapeutika haben sich v.a. bewährt:

- Hemmstoffe der viralen für die Replikation benötigten Nucleinsäure-Polymerasen

- Hemmstoffe der viralen Proteasen, die für die Spaltung der primär synthetisierten Polyproteine in die funktionellen Proteine benötigt werden

Der Einsatz derartiger Wirkstoffe ist jedoch problematisch, weil die Viren durch ihre hohe Mutationsrate rasch Resistenzen gegen die therapeutischen Stoffe entwickeln.

\section{Literatur}

\section{Monographien und Lehrbücher}

Adam D, Doerr HW, Link H (2003) Die Infektiologie, 1. Auflage, SpringerVerlag, Berlin Heidelberg New York

Dörries R, Geginat G (2004) Medizinische Mikrobiologie, 3. Auflage, Thieme-Verlag, Stuttgart

Evans AS, Kaslow RA (1997) Viral Infections of Humans. 4. Aufl., Plenum Publishing Cooperation, New York, London

Fields BN, Knipe DM, Howley PM (2000) Virology. 2 Bände, 3. Aufl., Lippincott-Raven Publishers., New York

Hacker J, Heesemann J (2005) Molekulare Infektionsbiologie - Interaktionen zwischen Mikroorganismen und Zellen. 2.Auflage, Spektrum Akademischer Verlag, Heidelberg

Hahn H, Falke D, Kaufmann SHE (2004) Medizinische Mikrobiologie und Infektiologie. 5. Aufl., Springer-Verlag, Berlin Heidelberg New York

Jilg W (1996) Schutzimpfungen - Kompendium zum aktiven und passiven Impfschutz. ecomed Verlagsgesellschaft, Landsberg

Kayser FH, Bienz KA, Eckert J, Zinkernagel RM (2005) Medizinische Mikrobiologie. 9. Auflage, Georg Thieme Verlag, Stuttgart

Köhler W, Eggers HJ, Fleischer B (2001) Medizinische Mikrobiologie. 7. Aufl., Gustav-Fischer-Verlag, Stuttgart
Levine AJ (1991) Viren - Diebe, Mörder und Piraten. Spektrum Akademischer Verlag, Heidelberg

Marre R, Mertens T, Trautmann M, Vanek E (2000) Klinische Infektiologie. 1. Aufl., Urban und Fischer-Verlag, München

Medina-Kauwe LK (2003) Endocytosis of adenovirus and adenovirus capsid proteins Advanced Drug Delivery Reviews 55:1485-1496

Meier O, Greber UF (2004) Adenovirus endocytosis. J Gene Med 6:S152S163

Mims CA, Playfair JHL, Roitt IM (2002) Medizinische Mikrobiologie. Verlag Ullstein-Mosby, Wiesbaden

Modrow S, Falke D, Truyen U (2003) Molekulare Virologie. 2. Aufl., Spektrum Akademischer Verlag, Heidelberg

Modrow S (2001) Viren, Grundlagen, Krankheiten, Therapien. Serie Wissen. 1. Aufl., Verlag C.H. Beck, München

Russel CJ, Jardetzky TS, Lamb RA (2001) Membrane fusion maschines of paramyxoviruses: capture of intermediates of fusion. EMBO J 20:4024-4034

Thomssen R (2001) Schutzimpfungen, Grundlagen, Vorteile, Risiken. Serie Wissen. 1. Aufl., Verlag C.H. Beck, München

\section{Links im Netz}

- www.lehrbuch-medizin.de/biochemie 